\title{
Does Manager Ability Influence Prospectus Earnings Quality and IPO Underpricing?
}

\author{
Stephanie A. Hairston ${ }^{1}, \mathrm{Ji} \mathrm{Yu}^{2} \&$ Zenghui $\mathrm{Liu}^{3}$ \\ ${ }^{1}$ School of Accountancy, Georgia Southern University, USA \\ ${ }^{2}$ College of Business, State University of New York at New Paltz, USA \\ ${ }^{3}$ College of Business and Economics, Western Washington University, USA \\ Correspondence: Ji Yu, State University of New York at New Paltz, USA. E-mail: yuj@ newpaltz.edu
}

Received: November 15, 2018

Accepted: November 29, 2018

Online Published: December 4, 2018

doi:10.5430/afr.v8n1p1

URL: https://doi.org/10.5430/afr.v8n1p1

\begin{abstract}
Prior literature suggests that manager ability influences several factors, including financial reporting quality, key to the bargaining power of an issuing firm during their initial public offering (IPO). However, we also know that high ability managers are better able to engage in and conceal opportunistic behavior which may dampen any positive effects their abilities have in the IPO process. Given the conflicting affect that managerial ability may have on financial reporting and firm performance in the IPO setting, we examine the impact of manager ability on prospectus earnings quality and IPO underpricing. We find that IPO firms with high ability managers tend to have better earnings quality and are less underpriced than firms with low ability managers. We also find preliminary evidence that equity ownership strengthens the relationship between manager ability and IPO underpricing. Our findings are consistent with the streams of literature suggesting that better managers produce higher quality earnings and raise more capital during the IPO to invest in future growth opportunities if they are closely monitored. These findings should be useful to issuing firms considering hiring high caliber managers, investors in evaluating IPO firms, and researchers in examining the influence of human capital on IPO underpricing.
\end{abstract}

Keywords: manager ability, agency theory, IPO underpricing, earnings quality

\section{Introduction}

Manager ability has been linked to several factors that influence financial reporting quality including earnings forecast accuracy, the accuracy of accrual estimates, the effectiveness of internal controls, and firms' likelihood to issue restatements (Baik et al., 2011; Demerjian et al., 2013; Hoitash et al., 2012; Li et al., 2010). (Note 1) These factors could significantly influence the level of information asymmetry surrounding the valuation of an IPO. However, this literature does not suggest that manager ability unambiguously improves financial reporting quality, but also provides evidence that high ability managers are better able to recognize internal control weaknesses and exploit fraud opportunities (Demerjian et al. 2016; Frank \& Obloj 2013; Gul et al. 2018). As such, in this study we examine the relationship between manager ability, prospectus earnings quality, and IPO underpricing.

Information asymmetry arises in the IPO process because outside investors have limited information about IPO firms, except that from the IPO prospectus, and they face difficulty in evaluating IPO firms due to their limited operating history; whereas, firm insiders, particularly firm managers, have access to extensive information regarding the internal operation of the firm and its economic potential (Park \& Patel, 2015). Due to the lack of publicly available information for IPO firms, firm managers, particularly high ability managers, are in a better position and have incentive to misrepresent the firm to potential investors given that the potential returns to inaccurate or incomplete disclosure may be significant. However, Cheung et al. (2017) suggest that strong monitoring mechanisms reduce management's ability to engage in and conceal "rent-seeking" behavior. During an IPO, firm managers are subject to more stringent internal and external monitoring from auditors, governmental agencies, underwriters, institutional investors, the media, and through internal control systems (Chemmanur \& Paeglis, 2005; Hoitash et al., 2012; Li et al., 2010; Venkataraman et al., 2008). As such, we anticipate and find that manager ability is positively associated with prospectus earnings quality and negatively associated with IPO underpricing because of the monitoring intensity during the IPO process. 
Given the potentially confounding nature of manager ability on the IPO process, we use a sample of 2,964 IPOs during the period from 1980 to 2011 to examine the impact of manager ability on prospectus earnings quality and IPO underpricing. Following prior literature (Bhagat, Bolton, \& Subrmanian, 2011; Demerjian et al., 2012), we use multiple measures of manager ability and earnings quality to examine these relationships. We find that manager ability is positively associated with three of our four earnings quality measures, and that all of our manager ability measures are associated with less IPO underpricing after controlling for other firm characteristics known to affect IPO underpricing. Our results are robust to several factors including alternative sample selection criteria and control variables. We also find preliminary evidence that equity ownership strengthens the relationship between manager ability and IPO underpricing. This result suggests that management's ownership interest may influence their behavior during the IPO process. Overall, our findings suggest that manager ability influences the outcome of an IPO.

Our study expands the body of literature examining the role of human capital in the IPO process and contributes to the literature in several ways. First, we extend the findings of Chemmanur and Paeglis (2005) that "better and more reputable managers convey the intrinsic value of their firm more credibly to outsiders (Chemmanur and Paeglis 2005)," by providing evidence that high ability managers influence IPO underpricing through their impact on the quality of earnings presented in the IPO prospectus. Our findings are also consistent with high ability managers behaving less opportunistically in the IPO setting because they are under more scrutiny from external and internal monitors during the IPO process. Second, we find that the relationship between manager ability and IPO underpricing is not mitigated when controlling for earnings quality, which suggests that managers also influence IPO underpricing more directly based on their superior ability to allocate firm capital. Finally, we find preliminary evidence that equity ownership strengthens the relationship between manager ability and IPO underpricing, suggesting that CEOs with high levels of equity-based compensation more actively monitor the IPO process.

We also recognize the limitations of our findings; specifically, given our limited sample size, our results may not be generalizable to all IPO firms. However, in our analysis we attempt to address this issue by comparing our sample distribution and results to those of similar studies. Overall, we find that our sample distribution is comparable to prior literature and that our control variables are consistent with prior literature. In addition, we also remove some sample selection criteria that limit our sample size in our robustness tests and find that our results remain qualitatively the same with the increased sample sizes. Overall, our results provide empirical support that contributes to the human capital literature suggesting that manager ability influences the IPO process. The findings of this study should be useful to issuing firms considering hiring high caliber managers, investors in evaluating IPO firms, and researchers interested in the impact of human capital on IPO underpricing.

The remainder of this paper is organized as follows: section two presents the literature review and hypothesis development, section three describes the research design and empirical models, section four presents the empirical results, section five presents the sensitivity analysis and robustness checks, and section six concludes.

\section{Literature Review and Hypothesis Development}

\subsection{IPOs and Information Asymmetry}

With the exception of the IPO prospectus, outside investors have limited information about IPO firms and face difficulty in evaluating them due to their limited operating history; whereas, firm insiders, particularly firm managers, have access to significantly more information regarding the operation of the firm, its economic potential, and the effectiveness of its management and employees (Park \& Patel, 2015). Prior research also suggests that an IPO prospectus is recognized by investors as, "the most detailed and precise information about the issuing firm (Bhabra and Pettway 2003, p. 370)." In addition, the prospectus "is approved by the SEC for material accuracy, is a legal document that protects the issuer and the underwriter because it is written proof that the investor was provided with all of the material facts related to the offering (Bhabra and Pettway, 2003 p. 370)." Although owners are required to provide accurate information regarding the current performance and financial condition of the IPO firm in the prospectus, laws cannot require full disclosure. Additionally, Cohen \& Dean (2005) also argue that most of the information provided about IPO firms in their prospectus is screened by firm managers, who have an incentive to misrepresent the firm to potential investors. This suggests that firm insiders have an incentive to misrepresent the firm to potential investors given the potential returns to inaccurate or incomplete disclosure.

Prior literature also suggests that better managers may behave opportunistically to increase compensation or to protect their reputation (Cheng \& Warfield, 2005; Cheng, Warfield, \& Ye, 2011; Grant et al., 2009; Tan \& Jamal, 2006). Tan \& Jamal (2006) demonstrate that high foresight managers that have knowledge about future earnings are better able to smooth earnings than low foresight managers with less knowledge. Given that there is relatively little publicly available financial information on IPO firms, this literature suggests that an IPO is an optimal setting for 
opportunistic managers to manipulate earnings. However, several studies also imply that managers' behavior is dependent upon the relative consequences of behaving opportunistically (Francis et al., 2008; Demerjian et al., 2016; Cheung et al., 2017).

\subsection{Manager Ability and Financial Reporting Quality}

Prior literature has linked manager ability to several factors that influence financial reporting quality including earnings forecast accuracy, the accuracy of accrual estimates, the effectiveness of internal controls, and firms' likelihood to issue restatements (Baik et al., 2011; Demerjian et al., 2013; Hoitash et al., 2012; Li et al., 2010). Baik et al. (2011) provide evidence that high ability CEOs issue higher quantities of and more accurate forecasts relative to lower ability CEOs because they have an incentive to keep the market abreast of changes in their firms' economic environment. Their study suggests that more accurate information is transmitted to the markets by high ability CEOs than their low ability counterparts. Demerjian et al. (2013) provide evidence that higher ability managers are associated with fewer restatements, higher earnings and accruals persistence, and higher quality accrual estimates. Krishnan and Wang (2015) find that audit fees and the likelihood of issuing a going concern opinion decrease in manager ability, which implies that manager ability mitigates auditors' risk exposure. This literature suggests that higher manager ability is associated with improved firm performance, financial reporting quality, and a decreased risk of firm failure.

However, prior literature does not suggest that high ability managers unambiguously improve financial reporting quality and firm performance (Cheung et al., 2017; Demerjian et al., 2016; Gul et al., 2018). A significant body of literature also suggests that the same attributes that make high ability managers value maximizers for their firms, such as organizational and industry knowledge, increase their ability to recognize internal control weaknesses and exploit fraud opportunities (Gul et al., 2018). Prior literature suggests that a better understanding and more intimate knowledge of systems and processes may allow managers to circumvent internal control procedures without being detected (Dellaportas, 2013). Similarly, Frank \& Obloj (2013) and Demerjian et al. (2016) demonstrate that high ability managers are better able and less likely to be caught managing earnings. In addition, Francis et al. (2008) find that more reputed CEOs are associated with lower earnings quality. As a result of their talents and knowledge, high ability managers are in a better position to "game" the system and engage in rent-seeking behavior than are their low ability counterparts. However, Cheung et al. (2017) suggest that although high ability managers' are in a better position to engage in and conceal "rent-seeking" behavior, their ability to do so is curtailed through strong monitoring mechanisms. Specifically, Cheung et al. (2017) find that more able managers utilize discretion more effectively when closely monitored via internal and/or external monitoring mechanisms. As such, we should expect to see better financial reporting quality among high ability managers that are subject to more stringent internal and/or external monitoring.

\subsection{Manager Ability and the IPO Setting}

During an IPO, firms are under a significant amount of scrutiny by auditors, underwriters, analysts, the media, and potential investors (Chemmanur \& Paeglis 2005; Venkataraman et al. 2008). Venkataraman et al. (2008) provide evidence that auditors are more conservative when auditing the financial statements in an IPO prospectus due to the increased litigation exposure surrounding the IPO process. Additionally, Chemmanur and Paeglis (2005) show that high management quality is associated with higher levels of institutional ownership, which is indicative of higher levels of monitoring. (Note 2) IPO firms are also subject to public reporting requirements imposed by government regulatory bodies such as the Securities and Exchange Commission (SEC). This literature suggests that there is stronger monitoring of firms during an IPO, which increases the severity of consequences faced by managers engaging in opportunistic behavior. Given the heightened scrutiny of firms during an IPO, high ability managers should be more likely to report higher quality accounting information in the IPO prospectus.

In addition to the external monitoring mechanisms present for IPO firms, prior literature also suggests that high ability managers are subject to more stringent internal monitoring stemming from more robust internal control systems (Hoitash et al. 2012; Li et al. 2010). Specifically, Hoitash et al. (2012) find that firms with more able managers have more robust internal control systems. This literature suggests that high ability managers are more constrained by strong internal control systems than are their low ability counterparts. Strong internal control systems make it more difficult for even high ability managers to find means to exploit internal control weaknesses.

Although high ability managers are better able to conceal earnings management and allude the consequences of such behavior, Cheung et al. (2017), suggest that such a use of managerial discretion can be significantly reduced if managers are closely monitored. IPO firms are closely monitored during the IPO process by both internal and external monitoring mechanisms. This implies that although the IPO may be an optimal time for high ability 
managers to manage earnings, they are unable to do so because of the scrutiny surrounding the IPO process. As a result of close monitoring during the IPO, high ability managers have limited discretion available to engage in opportunistic behavior and may be more likely to use their talents to maximize firm value rather than attempting to extract private benefits from their firms.

Prior literature provides evidence that high ability managers can increase firm value through their influence over financial reporting quality (Baik et al., 2011; Demerjian et al., 2013; Hoitash et al., 2012; Li et al., 2010). Manager ability is positively associated with earnings forecast accuracy and the accuracy of accrual estimates (Baik et al., 2011; Demerjian et al., 2013). Additionally, manager ability is negatively associated with the likelihood of issuing financial restatements (Demerjian et al., 2013). Given that the IPO prospectus is often the only and most detailed financial information available to investors prior to firms going public (Bhabra \& Pettway 2003), high ability managers under the scrutiny of external auditors, governmental agencies, and investors may be less likely to engage in "rent-seeking" behavior, resulting in disclosure of higher quality accounting information. As such, we expect IPO firms with high ability managers to report higher quality earnings in their prospectus filings than firms with lower ability managers.

H1: Manager ability is positively associated with earnings quality in IPO prospectus filings.

\subsection{Manager Ability and IPO Underpricing}

Prior literature suggests that the primary purposes of an IPO are to raise capital that enables firms to invest in future growth opportunities and to provide a public market for insiders to convert their shares to cash (Ritter \& Welch, 2002). IPO underpricing occurs when the IPO offer price is lower than its market close price at the end of the first trading day. If an IPO is underpriced, the firm does not raise the maximum amount of capital and insiders are not able to cash out of the firm at the highest price. As such, IPO underpricing is a suboptimal event because it results in firms "leaving money on the table." A significant body of literature suggests that IPO underpricing can be attributed to information asymmetry between firm managers and outside investors (Ball \& Shivakumar, 2008; Boulton et al., 2011; Butler et al., 2014; Leone et al., 2007; Ljungqvist, 2007; Teoh et al., 1998). Thus, to the extent that firm managers reduce information asymmetry, there should be less IPO underpricing.

Consistent with this theory, Boulton et al. (2011) provide evidence that IPOs are underpriced less in countries where public firms produce higher quality earnings. More frequent and higher quality disclosures are also associated with less IPO underpricing (Boulton et al., 2011; Leone et al., 2007). In addition, Park \& Patel (2005) find that firms can reduce IPO underpricing if they present clear information about their quality. Specifically, they find that IPO underpricing is low when the prospectus contains less ambiguous information that creates a more reliable signal conveying the quality of the IPO firm. This research implies that to the extent that managers influence financial reporting and disclosure quality they can use these means to reduce information asymmetry and signal the quality of their firm to the market.

Prior literature suggests that manager ability is positively associated with financial reporting quality, particularly when high ability managers are closely monitored (Baik et al., 2011; Cheung et al., 2017; Demerjian et al., 2012; Demerjian et al., 2013). Baik et al. (2011) provide evidence that high ability CEOs enhance the credibility of management forecasts, given that the markets are more responsive to high ability CEO forecasts. In addition, Baik et al. (2011) suggest that high ability managers have incentives to keep the market abreast of changes in their firm's economic environment relative to their low ability counterparts. Leverty and Grace (2012) find that manager ability is negatively associated with the amount of time a firm spends in distress and the likelihood of firm failure, which is indicative of superior firm performance among high ability managers. Chemmanur \& Paeglis (2005) find that better and more reputable managers "convey the value of their firms more credibly to the equity markets," thus reducing information asymmetry, and resulting in lower IPO underpricing. Given their influence on the financial reporting process and overall firm performance, high ability managers are likely to influence IPO underpricing. Specifically, if the IPO prospectus of firms with high ability managers provide higher quality accounting information, that reduces information asymmetry and thus IPO underpricing (Ball \& Shivakumar, 2008; Boulton et al., 2011; Butler et al., 2014; Jackson, Wilcox, \& Strong, 2002; Leone et al., 2007; Ljungqvist, 2007; Teoh et al., 1998). As such, we expect to find a negative relationship between manager ability and IPO underpricing. We state our second hypothesis as follows:

H2: Manager ability is negatively associated with IPO underpricing. 


\section{Research Design and Empirical Models}

\subsection{Sample Selection and Data}

We obtain the U.S. IPOs of common equity information from the Thomson Financial Securities Data new issues database (SDC). Financial statement information and financial market information is obtained from COMPUSTAT and CRSP. (Note 3) Our original sample from SDC consists of 11,399 IPOs from 1976-2011. (Note 4) Following Zheng \& Stangeland (2007), American Depository Receipts (ADRs), unit issues, certificates, beneficial interest, closed-end funds, real estate investment trusts (REITs), and banking firms are excluded from the sample. All firms in the sample are covered by Jay Ritter's data set of IPO founding dates. Firms are also excluded if they are missing financial data necessary to calculate the control variables used in the regression model. Given the significant reduction in sample size related to this criterion, we compare the distribution of our measures to prior literature in section 4.1 to alleviate some concern related to sample bias. Our final sample consists of 2,964 U.S. IPOs from fiscal years 1980 to 2011. (Note 5)

Table 1. Sample Selection Procedure.

\begin{tabular}{ll}
\hline & $\begin{array}{l}\text { Number of } \\
\text { observations }\end{array}$ \\
\hline $\begin{array}{l}\text { Initial Public Offering (IPO) of common shares issued in US from SDC (1976-2011) after } \\
\text { merging Ritter's dataset of IPO founding dates }\end{array}$ & 6,913 \\
Less: & \\
$\quad$ ADR and Unit Issues & $(118)$ \\
Certificates and Beneficial Interests & $(28)$ \\
Closed-end funds and Real Estate Investment Trust (REITs) & $(110)$ \\
Banking Firms (SIC 6000-6199) & $(404)$ \\
Observations with offer prices less than five dollars & $(412)$ \\
$\quad \begin{array}{l}\text { Missing financial data necessary to calculate control variables or } \\
\text { manager ability measures }\end{array}$ & $\underline{(2,877)}$ \\
Final Sample & 2,964 \\
\hline
\end{tabular}

\subsection{IPO Underpricing Measure}

IPO underpricing is a widely observed phenomenon internationally. If the offer price set by investment banks is lower than the first day closing price, the difference is referred to as IPO underpricing. IPO underpricing is an incentive for investors to bear the risks of buying the shares when a firm goes public. Following Leone, Rock, \& Willenborg (2007), equation (1) specifies the formula used to calculate IPO underpricing:

$$
\text { IPO Underpricing }=\ln [1+(\text { first day market close price }- \text { offer price }) / \text { offer price }]
$$

\subsection{Earnings Quality Measures}

Like DuCharme, Malatesta, \& Sefcik (2001) and Armstrong et al. 2016 we rely on discretionary accruals as our measure of earnings quality. Accruals reflect both the choice of accounting methods and the recognition timing for revenues and expenses, asset write-downs, and changes in accounting estimates (DuCharme et al., 2001). Prior literature also suggests that discretionary accruals proxy for information asymmetry given that accounting accruals are more prone to management discretion and manipulation (Aboody, Hughes, \& Liu, 2005). As such, we believe that accrual quality is an informative measure of earnings quality given that the mapping of accruals into cash flow does involve some discretionary accounting choices. We use four empirical proxies for discretionary accruals that are prevalent in the accounting literature as estimates of earnings management through accruals (Sun, Salama, Hussainey, \& Habbash, 2010; Tong \& Miao, 2011).

Consistent with prior literature we use signed discretionary accrual quality as our measure of accrual quality (Teoh et al., 1998, Ducharme et al., 2001; Armstrong et al., 2016). (Note 6) We estimate four measures of accrual quality: (1) discretionary accruals based on the Jones (1991) model; (2) discretionary accruals based on the modified Jones model (Dechow, Sloan, \& Sweeney, 1995); (3) discretionary accruals controlling for ROA based on Kothari, Leone, \& Wasley (2005); and (4) an aggregate average value of the three individual metrics (Boulton et al., 2011). We reverse code all four measures of discretionary accruals, multiplying them by negative one because the discretionary 
accruals are inverse indicators of earnings quality. After making these adjustments we note that higher (lower) values of the earnings quality variables are indicative of better (worse) earnings quality.

Our first accrual quality measure is the discretionary accruals based on the Jones (1991) model. The Jones (1991) model is estimated as follows:

$$
A c c_{i t}=\alpha\left(\frac{1}{\text { Assets }_{i t-1}}\right)+\beta_{1} \Delta \operatorname{Rev}_{i t}+\beta_{2} P P E_{i t}+\varepsilon_{i t}(\text { Note 7) }
$$

Discretionary accruals are the residual from the cross-sectional regression of each year within the same industry (two-digit SIC). An IPO firm's expected accruals are estimated from equation (2) using an estimation sample of all two-digit SIC code peers (excluding the issuers). The regression model presented in equation (2) provides the benchmarks for non-discretionary accruals. The IPO firm's discretionary accruals are calculated by subtracting non-discretionary accruals from actual accruals.

Our second measure of accrual quality is discretionary accruals estimated from the modified Jones model (Dechow et al. 1995). Dechow et al. (1995) find that adjusting the Jones (1991) model to detect revenue-based earnings management generated the fewest type II errors in detecting earnings management. The modified Jones measure is calculated using the following model:

$$
A c c_{i t}=\alpha\left(\frac{1}{\text { Assets }_{i t-1}}\right)+\beta_{1}\left(\Delta \operatorname{Rev}_{i t}-\Delta \operatorname{Rec}_{i t}\right)+\beta_{2} P P E_{i t}+\varepsilon_{i t} \quad(\text { Note } 8)
$$

Similar to the Jones (1991) model, discretionary accruals are the residual from the cross-sectional regression of each year within the same industry (two-digit SIC). The regression model presented in equation (3) provides the benchmarks for non-discretionary accruals for an IPO. The IPO firm's discretionary accruals are calculated by subtracting non-discretionary accruals from actual accruals.

Our third measure of accrual quality is discretionary accruals controlling for ROA based on Kothari et al. (2005). (Note 9) Discretionary accruals controlling for ROA are measured using the following model:

$$
\operatorname{TAcc}_{i t}=a_{1}\left(\frac{1}{\text { Assets }_{i t-1}}\right)+a_{2} \Delta \text { Sales }_{i t}+a_{3} P P E_{i t}+a_{4} R O A_{i t}+\varepsilon_{i t}(\text { Note 10) }
$$

Return on assets (ROA) is used as the performance matching control variable, and discretionary accruals are the residual from the cross-sectional regression of each year within the same industry (two-digit SIC). Performance measures, such as earnings and cash flow from operations (Dechow et al. 1995), are winsorized at one percent level to limit the impact of extreme observations. The regression model presented in equation (4) provides the benchmarks for non-discretionary accruals for an IPO. The IPO firm's discretionary accruals are calculated by subtracting non-discretionary accruals from actual accruals. Our final measure of earnings quality is an aggregate average of the first three earnings quality metrics (Boulton et al., 2011). In calculating our aggregate average earnings quality measure, we average our three accrual quality measures. We again note that all four of our earnings quality measures are reverse coded so that higher (lower) values indicate better (worse) earnings quality.

\subsection{Manager Ability Measures}

We use the manager ability score (MA-Score) developed by Demerjian et al. (2012) to assess the relationship between manager ability, prospectus earnings quality, and IPO underpricing. Demerjian et al.'s (2012) manager ability measure is based on the management team's efficiency in transforming resources to revenue relative to their industry peers. Specifically, higher ability managers should be able to generate higher revenue for a given level of resources, or minimize the resources used to generate a given level of revenue (Demerjian et al., 2012). This measure is particularly relevant in an IPO setting because IPOs result in an influx of available capital for firm investment. As such, managers that can efficiently and effectively manage firm resources are more valuable to investors, and firms with these managers should have higher share prices and are less likely to be underpriced at the IPO.

In constructing MA-Score, Demerjian et al. (2012) use data envelopment analysis (DEA) to estimate total firm efficiency. (Note 11) Total firm efficiency is estimated using one output and seven inputs. The one output is total revenue because the primary objective of the firm is to generate revenue. The authors suggest that firms that are the most efficient are those that produce the maximum sales at the lowest costs. The first five inputs are assets the company invests in that are expected to affect revenue generation: net property, plant, and equipment (PP\&E), net operating leases, net research and development (R\&D), purchased goodwill, and other acquired and capitalized intangibles. The remaining two inputs are cost of goods sold and selling, general, and administrative expenses, which are designed to account for the cost of inventory as well as sales generated from advertising and through the quality of the sales team (Demerjian et al., 2013). As such, the DEA optimization model compares the sales generated by 
each firm in an industry, conditional on seven inputs used by the firm: cost of goods sold (COGS), selling general, and administrative expenses (SG\&A), net PP\&E (PPE), net operating leases (OpsLease), net research and development (R\&D), purchased goodwill (Goodwill), and other intangible assets (OtherIntan). The authors use DEA to estimate a solution for the following optimization problem:

$$
\max _{v} \theta=\frac{\text { Sales }}{v_{1} C O G S+v_{2} S G \& A+v_{3} P P E+v_{4} O p s L e a s e+v_{5} R \& D+v_{6} \text { Goodwill }+v_{7} \text { OtherIntan }} \quad \text { (Note 12) }
$$

The optimization finds the optimal weights for the firm-specific vector of the seven inputs by comparing each of firm's input choices to other firms in the estimation group (Demerjian et al., 2013). A firm's DEA score indicates its overall efficiency. According to Demerjian et al. (2013) the DEA efficiency measure has a value between zero and one, that reflects the constraints in the optimization program. Observations with a value of one are the most efficient and the set of firms with efficiency equal to one trace a frontier through the efficient set of possible input combinations. Observations with efficiency measures less than one fall below the frontier. A firm with a score of less than one would need to reduce costs or increase revenues to achieve efficiency.

Although the firm efficiency measure produced by the DEA estimation could be used to assess manager ability, Demerjian et al. (2012) argue that the measure is attributable to both firm- and manager-specific efficiency drivers and may result in an under or overestimation of manager ability. As such, the DEA generated efficiency measure is then modified by removing "key firm-specific characteristics expected to aid or hinder management's efforts, including firm size, market share, positive free cash flow, and firm age, which aid management, and complex multi-segment and international operations, which challenge management (Demerjian et al., 2012, p. 1230).” The authors accomplish this removal of firm-specific characteristics by estimating the following Tobit regression model by industry:

Firm Efficiency $=$ $\alpha_{0}+\alpha_{1} \operatorname{Ln}($ Total Assets $)+\alpha_{2}$ Market Share $+\alpha_{3}$ Positive Free Cash Flow $+\alpha_{4}$ Ln $($ Age $)+$ $\alpha_{5}$ BusinessSegmentConcentration $+\alpha_{6}$ Foreign Currency Indicator + Year Indicators $+\varepsilon$. (Note 13$)$

MA-Score is the residual from the estimation of the firm efficiency model, which Demerjian et al. (2012) attribute to the management team. MA-Score data was collected from Demerjian's website for the years 1980-2011. (Note 14) Higher (lower) values of MA-Score indicate more (less) able managers. Demerjian et al. (2012) perform several validity tests for this measure which are consistent with the variable reflecting manager ability distinct from the firm. (Note 15)

Prior literature also provides evidence that the Demerjian et al. (2012) MA-Score is positively associated with earnings quality (Beber \& Fabbri, 2012; Iqbal, 2015), which further supports its use as our primary manager ability measure. The Demerjian et al. (2012) measure of manager ability focuses on the operational and industry knowledge of managers as the primary source of their ability. Overall, their results imply that high ability managers operate their businesses more effectively than low ability managers. In addition, many MA-Score observations are available during the pre-IPO period. (Note 16) However, we also note that there are possible sources of measurement error in the Demerjian et al. (2012) manager ability measure, including the ability of management to manipulate accounting variables used to measure manager ability. As such, we also use two alternative measure of manager ability, CEO compensation and CEO tenure. Prior literature shows that highly compensated managers tend to operate firms more efficiently and generate higher revenues than low ability managers with similar resources (Demerjian et al., 2012; Demerjian et al., 2013). CEO tenure is positively associated with industry and business knowledge, both of which are indicative of manager ability (Baatwah, Salleh, \& Ahmad, 2015). We measure CEO compensation as the natural logarithm of the salary and bonus of the firm CEO in year $t$, and we measure CEO tenure as the number of years an executive has been listed as CEO by Execucomp as of one year prior to the IPO date.

\subsection{Empirical Models}

Our first regression model investigates the effects of manager ability on IPO prospectus earnings quality (Francis et al., 2008).

$$
\begin{gathered}
E Q i=\beta_{0}+\beta_{1} \text { Ability }_{1}+\beta_{2} \text { Lnat }+\beta_{3} \text { Stdcflow }+\beta_{4} \text { Stdsales }+\beta_{5} \text { Opercycle }+\beta_{6} \text { NegEarn }+\beta_{7} \text { CapIntensity }+ \text { Industry and } \\
\text { Year Fixed effects }+\varepsilon(\text { Note 17) }
\end{gathered}
$$

All variables used in the regression model are defined in Appendix A. In this model we use four proxies to measure earnings quality: $E Q_{1}$ is the Jones (1991) model; $E Q_{2}$ is the modified Jones (1991) model (Dechow et al., 1995); $E Q_{3}$ is discretionary accruals controlling for ROA (Kothari et al., 2005); and AggreEQ is equal to the aggregate average of $E Q_{1}, E Q_{2}$ and $E Q_{3}$. Each earnings quality measure is reverse coded so that higher (lower) values indicate better 
(worse) earnings quality. The regression model controls for firm characteristics identified in prior literature that influence earnings quality (Francis et al., 2008). Firm characteristics include firm size (Lnat), cash flow and revenue volatility (Stdcflow and Stdsales), length of the operating cycle (Opercycle), negative earnings (NegEarn), and capital intensity (CapIntensity).

The following regression model is used to examine the relationship between manager ability and IPO underpricing.

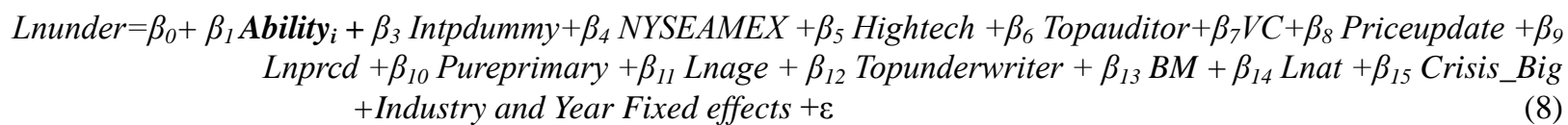

All variables used in the regression model are defined in Appendix A. The regression model controls for firm and deal characteristics identified in prior literature that influence IPO underpricing (Barry et al., 1990; Beatty \& Ritter, 1986; Bradley et al., 2004; Carter \& Manaster, 1990; Lowry et al., 2010). Firm characteristics include firm age (Lnage), exchange market where the IPO is listed (NYSEAMEX), and whether the firm is in the technology industry (Hightech). We also include firms' total asset before the IPO (Lnat) and book-to-market ratio (BM) to control for firm size and growth opportunities. Deal characteristics include IPO proceeds (Lnprcd), (Note 18) IPO underwriter bank rank (Topunderwriter), whether the firm's offer price is an integer (Intpdummy), and auditor's reputation rank (Topauditor).

\section{Empirical Results}

\subsection{Descriptive Statistics}

Table 2 lists descriptive statistics of all variables used in our regression models. Given that a significant number of observations are removed due to missing financial data (2,877 observations), our results could be biased toward firms that disclose more information in the IPO prospectus. To alleviate some concern related to sample bias, we compare our descriptive statistics to those from similar studies. Specifically, we benchmark our IPO variables against those reported in Butler et al. (2014) and Bajo \& Raimondo (2017). (Note 19) We note that overall the distribution of our sample is similar to prior literature. As such, although our results should be interpreted with some caution, we believe that our findings are representative of and generalizable to IPO firms. 
Table 2. Descriptive Statistics.

\begin{tabular}{|c|c|c|c|c|c|c|}
\hline Variable & $\mathrm{N}$ & Mean & Std Dev & 25th Pctl & 50th Pctl & 75th Pctl \\
\hline Underprice & 2,964 & 0.168 & 0.259 & 0.005 & 0.087 & 0.232 \\
\hline Abilityl & 2,964 & 0.007 & 0.170 & -0.096 & 0.005 & 0.105 \\
\hline Ability2 & 575 & 6.312 & 0.679 & 5.886 & 6.215 & 6.745 \\
\hline Ability3 & 576 & 1.537 & 0.932 & 0.693 & 1.609 & 2.197 \\
\hline$E Q_{1}$ & 2,072 & 0.260 & 0.260 & 0.054 & 0.146 & 0.374 \\
\hline$E Q_{2}$ & 2,068 & 0.270 & 0.280 & 0.057 & 0.155 & 0.389 \\
\hline$E Q_{3}$ & 2,068 & 0.250 & 0.250 & 0.058 & 0.149 & 0.365 \\
\hline AggreEQ & 2,068 & 0.270 & 0.260 & 0.063 & 0.158 & 0.381 \\
\hline Stdcflow & 1,554 & 0.179 & 0.249 & 0.054 & 0.095 & 0.191 \\
\hline Stdsales & 1,554 & 0.396 & 0.389 & 0.165 & 0.286 & 0.477 \\
\hline Opercycle & 1,554 & 4.665 & 0.863 & 4.239 & 4.750 & 5.205 \\
\hline NegEarn & 1,554 & 0.414 & 0.493 & 0.000 & 0.000 & 1.000 \\
\hline CapIntensity & 1,554 & 0.325 & 0.303 & 0.101 & 0.212 & 0.460 \\
\hline Intpdummy & 2,964 & 0.808 & 0.394 & 1.000 & 1.000 & 1.000 \\
\hline NYSEAMEX & 2,964 & 0.168 & 0.374 & 0.000 & 0.000 & 0.000 \\
\hline Hightech & 2,964 & 0.440 & 0.496 & 0.000 & 0.000 & 1.000 \\
\hline Topauditor & 2,964 & 0.837 & 0.370 & 1.000 & 1.000 & 1.000 \\
\hline$V C$ & 2,964 & 0.448 & 0.497 & 0.000 & 0.000 & 1.000 \\
\hline Priceupdate & 2,964 & 1.000 & 0.137 & 0.923 & 1.000 & 1.081 \\
\hline Proceed & 2,964 & 79.543 & 123.373 & 18.900 & 41.600 & 83.400 \\
\hline Lnprcd & 2,964 & 3.641 & 1.124 & 2.923 & 3.665 & 4.332 \\
\hline Pureprimary & 2,964 & 0.590 & 0.492 & 0.000 & 1.000 & 1.000 \\
\hline Age & 2,964 & 17.362 & 21.987 & 5.000 & 9.000 & 18.000 \\
\hline Lnage & 2,964 & 2.340 & 0.979 & 1.609 & 2.197 & 2.944 \\
\hline Topunderwriter & 2,964 & 0.540 & 0.498 & 0.000 & 1.000 & 1.000 \\
\hline$B M$ & 2,964 & 0.594 & 35.851 & -0.029 & 0.142 & 0.287 \\
\hline \multicolumn{7}{|l|}{ Total Assets } \\
\hline (in millions) & 2,964 & 277.167 & 821.955 & 17.100 & 45.300 & 151.4 \\
\hline Lnat & 2,964 & 3.674 & 1.737 & 2.565 & 3.541 & 4.671 \\
\hline Crisis_Big & 2,964 & 0.014 & 0.118 & 0.000 & 0.000 & 0.000 \\
\hline
\end{tabular}

Note: This table reports the summary statistics for all variables based on 2,964 IPOs during the period 1980-2011. All variables are defined in Appendix A. All variables are winsorized at the $1^{\text {st }}$ and $99^{\text {th }}$ percentile.

In our sample, average underpricing is 16.8 percent as compared to 20.14 percent in Butler et al. (2014). (Note 20) 44.8 percent of the IPOs in the sample are backed by venture capitalists as compared to 43.2 percent in Butler et al. (2014). 16.8 percent of the IPOs go public on premium stock exchanges such as the NYSE and AMEX, as compared to the 13.1 percent reported in Butler et al. (2014). Our sample IPO's average age is 17.362 years as compared to 14.92 years in Bajo and Raimondo (2017). The mean values of our manager ability measures are as follows: MA-Score developed by Demerjian et al. (2012) is 0.007, CEO compensation is 0.105, and CEO tenure is 1.537. (Note 21) 
Table 3. Correlation Coefficients

\begin{tabular}{|c|c|c|c|c|c|c|c|c|c|c|c|c|}
\hline & & 1 & 2 & 3 & 4 & 5 & 6 & 7 & 8 & 9 & 10 & 11 \\
\hline 1 & AggreEQ & - & & & & & & & & & & \\
\hline 2 & Ability1 & -0.021 & - & & & & & & & & & \\
\hline 3 & Ability 2 & -0.186 & 0.008 & - & & & & & & & & \\
\hline 4 & Ability 3 & -0.131 & 0.037 & $\mathbf{0 . 0 3 3}$ & - & & & & & & & \\
\hline 5 & Stdcflow & 0.284 & -0.156 & -0.036 & 0.007 & - & & & & & & \\
\hline 6 & Stdsales & 0.171 & 0.121 & -0.054 & 0.029 & 0.293 & - & & & & & \\
\hline 7 & Opercycle & 0.04 & -0.048 & 0.057 & 0.059 & 0.072 & -0.143 & - & & & & \\
\hline 8 & NegEarn & 0.203 & -0.371 & -0.076 & -0.059 & 0.368 & 0.013 & 0.007 & - & & & \\
\hline 9 & CapIntensity & -0.137 & -0.063 & 0.227 & -0.123 & -0.232 & -0.183 & -0.309 & -0.153 & - & & \\
\hline 10 & Lnunder & 0.118 & -0.055 & -0.18 & -0.066 & 0.099 & 0.049 & 0.035 & 0.142 & -0.169 & - & \\
\hline 11 & Intpdummy & 0.057 & -0.053 & -0.01 & -0.116 & 0.092 & 0.037 & 0.017 & 0.105 & -0.074 & 0.128 & - \\
\hline 12 & NYSEAMEX & -0.087 & 0.061 & 0.325 & -0.138 & -0.176 & -0.105 & -0.042 & -0.139 & 0.221 & -0.105 & -0.035 \\
\hline 13 & Hightech & 0.145 & -0.062 & -0.23 & 0.006 & 0.212 & -0.049 & 0.147 & 0.3 & -0.338 & 0.151 & 0.07 \\
\hline 14 & Topauditor & -0.009 & -0.051 & -0.013 & 0.049 & 0.017 & -0.029 & -0.037 & 0.1 & -0.018 & 0.102 & 0.072 \\
\hline 15 & $V C$ & 0.079 & -0.109 & -0.276 & -0.01 & 0.155 & -0.068 & 0.062 & 0.277 & -0.259 & 0.165 & 0.089 \\
\hline 16 & Priceupdate & 0.062 & -0.002 & -0.141 & -0.018 & 0.032 & 0.048 & -0.009 & 0.013 & -0.12 & 0.411 & 0.091 \\
\hline 17 & Lnprcd & 0.06 & -0.058 & 0.296 & -0.217 & -0.133 & -0.188 & -0.081 & 0.085 & 0.088 & 0.159 & 0.163 \\
\hline 18 & Pureprimary & 0.078 & -0.212 & 0.016 & -0.075 & 0.214 & 0.046 & 0.042 & 0.379 & -0.08 & 0.076 & 0.054 \\
\hline 19 & Lnage & -0.161 & 0.108 & 0.274 & 0.03 & -0.257 & -0.113 & -0.016 & -0.277 & 0.206 & -0.14 & -0.055 \\
\hline 20 & Topunderwriter & 0.054 & -0.079 & 0.098 & $-\mathbf{0 . 1 3 7}$ & -0.046 & -0.167 & -0.02 & 0.116 & 0.02 & 0.102 & 0.075 \\
\hline 21 & $B M$ & -0.003 & -0.005 & 0.009 & 0.05 & 0.009 & -0.006 & 0.047 & 0.012 & -0.008 & 0.001 & 0.007 \\
\hline 22 & Lnat & -0.118 & -0.002 & 0.451 & -0.172 & -0.366 & -0.283 & -0.078 & -0.144 & 0.299 & -0.017 & 0.031 \\
\hline 23 & Crisis_Big & -0.011 & -0.019 & 0.075 & -0.045 & -0.018 & -0.029 & -0.01 & 0.015 & 0.042 & -0.008 & -0.007 \\
\hline \multicolumn{13}{|c|}{ Table 3. (continued) } \\
\hline
\end{tabular}

\begin{tabular}{lllllllllllll}
\hline & 12 & 13 & 14 & 15 & 16 & 17 & 18 & 19 & 20 & 21 & 22 & 23 \\
\hline 1 & & &
\end{tabular}

\begin{tabular}{|c|c|c|c|c|c|c|c|c|c|c|c|c|c|}
\hline 1 & AggreEQ & & & & & & & & & & & & \\
\hline 2 & Ability 1 & & & & & & & & & & & & \\
\hline 3 & Ability2 & & & & & & & & & & & & \\
\hline 4 & Ability 3 & & & & & & & & & & & & \\
\hline 5 & Stdcflow & & & & & & & & & & & & \\
\hline 6 & Stdsales & & & & & & & & & & & & \\
\hline 7 & Opercycle & & & & & & & & & & & & \\
\hline 8 & NegEarn & & & & & & & & & & & & \\
\hline 9 & CapIntensity & & & & & & & & & & & & \\
\hline 10 & Lnunder & & & & & & & & & & & & \\
\hline 11 & Intpdummy & & & & & & & & & & & & \\
\hline 12 & NYSEAMEX & - & & & & & & & & & & & \\
\hline 13 & Hightech & -0.203 & - & & & & & & & & & & \\
\hline 14 & Topauditor & -0.013 & 0.061 & - & & & & & & & & & \\
\hline 15 & $V C$ & -0.236 & 0.368 & 0.132 & - & & & & & & & & \\
\hline 16 & Priceupdate & -0.047 & 0.094 & 0.069 & 0.073 & - & & & & & & & \\
\hline 17 & Lnprcd & 0.35 & 0.021 & 0.263 & 0.051 & 0.207 & - & & & & & & \\
\hline 18 & Pureprimary & -0.045 & 0.065 & 0.093 & $\mathbf{0 . 0 3 7}$ & -0.049 & $-\mathbf{0 . 0 3}$ & - & & & & & \\
\hline 19 & Lnage & 0.242 & -0.235 & 0.001 & -0.222 & -0.077 & 0.223 & -0.183 & - & & & & \\
\hline 20 & Topunderwriter & 0.222 & 0.051 & 0.159 & 0.125 & 0.075 & 0.545 & 0.009 & 0.12 & - & & & \\
\hline 21 & $B M$ & -0.009 & 0.016 & 0.01 & 0.016 & -0.002 & -0.005 & 0.006 & 0.01 & 0.02 & - & & \\
\hline 22 & Lnat & 0.478 & -0.185 & 0.04 & -0.121 & 0.001 & 0.774 & -0.077 & 0.42 & 0.45 & -0.002 & - & \\
\hline 23 & Crisis_Big & 0.048 & -0.027 & -0.043 & 0.023 & -0.063 & 0.007 & -0.034 & 0 & 0.03 & 0.021 & 0.03 & - \\
\hline
\end{tabular}

Note: This table presents the Pearson correlation coefficients for major variables used in our empirical analysis. These correlations are based on 2,964 IPO firms during the period 1980-2011. Correlations that are significant at the 10 percent level or better are indicated in bold. All variables are defined in Appendix A. 
Table 3 shows the correlation between all variables included in our regression model. We find that all three measures of manager ability are negatively correlated with IPO underpricing, which is consistent with our expectations in $\mathrm{H} 2$; however, contrary to our expectations, we find that manager ability is negatively associated with aggregate earnings quality. The negative relationship between earnings quality and manager ability may be due to the lack of control variables. However, these results are consistent with Demerjian et al. (2013). We further test the relation between earnings quality and manager ability in our multivariate tests, which provide more comprehensive results. We also find that the three measures of manager ability are positively correlated, which suggests that all of the measures are capturing some similar components of manager ability.

\subsection{Manager Ability and IPO Prospectus Earnings Quality}

We use equation (7), to estimate the effects of manager ability on IPO prospectus earnings quality. The primary variable of interest in the model is manager ability measured by Demerjian (2012), MA-Score (Ability $)_{1}$. (Note 22) In Table 4, we include four models and apply ordinary least square (OLS) regression of equation (7). Our dependent variable in model 1 is earnings quality measured using the Jones (1991) model $\left(E Q_{1}\right)$, model 2 measures earnings quality using the modified Jones (1991) model $\left(E Q_{2}\right)$ (Dechow et al. 1995), model 3 measures earnings quality using discretionary accruals controlling for ROA $\left(E Q_{3}\right)$ (Kothari et al., 2005), and model 4 measures earnings quality using our aggregate measure (AggreEQ).

Table 4. Manager Ability and Prospectus Earnings Quality.

\begin{tabular}{|c|c|c|c|c|c|c|c|c|}
\hline & Model 1 & & Model 2 & & Model 3 & & Model 4 & \\
\hline Abilityl & $\begin{array}{l}0.152 \\
(5.97)\end{array}$ & $* * *$ & $\begin{array}{l}0.245 \\
(3.57)\end{array}$ & **** & $\begin{array}{l}0.091 \\
(1.45)\end{array}$ & & $\begin{array}{l}0.169 \\
(3.23)\end{array}$ & $* * *$ \\
\hline Lnat & $\begin{array}{l}0.007 \\
(0.50)\end{array}$ & & $\begin{array}{l}0.008 \\
(0.50)\end{array}$ & & $\begin{array}{l}0.001 \\
(0.06)\end{array}$ & & $\begin{array}{l}0.006 \\
(0.43)\end{array}$ & \\
\hline Stdcflow & $\begin{array}{l}0.299 \\
(1.55)\end{array}$ & & $\begin{array}{l}0.354 \\
(1.44)\end{array}$ & & $\begin{array}{l}0.468 \\
(1.88)\end{array}$ & * & $\begin{array}{l}0.372 \\
(1.65)\end{array}$ & * \\
\hline Stdsales & $\begin{array}{l}0.213 \\
(3.04)\end{array}$ & $* * *$ & $\begin{array}{l}0.222 \\
(3.23)\end{array}$ & $* * *$ & $\begin{array}{l}0.143 \\
(4.35)\end{array}$ & $* * *$ & $\begin{array}{l}0.195 \\
(3.40)\end{array}$ & **** \\
\hline Opercycle & $\begin{array}{l}0.022 \\
(0.91)\end{array}$ & & $\begin{array}{l}0.050 \\
(2.18)\end{array}$ & $* *$ & $\begin{array}{l}0.054 \\
(4.24)\end{array}$ & $* * *$ & $\begin{array}{l}0.042 \\
(2.10)\end{array}$ & $* *$ \\
\hline NegEarn & $\begin{array}{l}-0.023 \\
(-2.52)\end{array}$ & $* *$ & $\begin{array}{l}-0.013 \\
(-1.84)\end{array}$ & * & $\begin{array}{l}-0.006 \\
(-0.89)\end{array}$ & & $\begin{array}{l}-0.015 \\
(-1.95)\end{array}$ & * \\
\hline CapIntensity & $\begin{array}{l}0.064 \\
(0.73)\end{array}$ & & $\begin{array}{l}0.082 \\
(0.82)\end{array}$ & & $\begin{array}{l}0.056 \\
(0.76)\end{array}$ & & $\begin{array}{l}0.075 \\
(0.82)\end{array}$ & \\
\hline Industry Fixed Effect & Yes & & Yes & & Yes & & Yes & \\
\hline Year Fixed Effect & Yes & & Yes & & Yes & & Yes & \\
\hline Observations & 1,554 & & 1,554 & & 1,554 & & 1,554 & \\
\hline Adjusted $R^{2}$ & 0.147 & & 0.150 & & 0.154 & & 0.155 & \\
\hline
\end{tabular}

Note: This table reports the coefficient estimates from OLS regression of earnings quality on manager ability. Model 1 presents the results using the Jones (1991) model $\left(E Q_{1}\right)$ as the earnings quality measure, model 2 presents the results using the modified Jones (1991) model $\left(E Q_{2}\right)$ based on Dechow et al. (1995) as the earnings quality measure, model 3 presents the results using discretionary accruals controlling for ROA $\left(E Q_{3}\right)$ based on Kothari et al. (2005) as the earnings quality measure, and model 4 presents the results using our aggregate earnings quality measure (AggreEQ). We include industry and year fixed effects in each of the models. Robust $t$ statistics appear in parentheses and are adjusted for intra-firm correlation with clustered standard errors.

*, **, *** Denote statistical significance at the 10 percent, 5 percent, and 1 percent levels, respectively. All other variables are defined in Appendix A. 
In Table 4, we find that manager ability is significantly and positively related to IPO prospectus earnings quality in three of our four model specifications $\left(E Q_{1}:\right.$ Ability $_{l}=0.152$, p-value $<0.001 ; E Q_{2}$ : Ability $=0.245$, p-value $<0.001$; AggreEQ: Ability $_{1}=0.169$, p-value $\left.=0.001\right)$. Although we do not find a significant relationship between earnings quality and manager ability in model 3 , we do note that the manager ability coefficient remains positive $\left(E Q_{3}\right.$ : Ability $_{I}=0.091, \mathrm{p}$-value $\left.=0.147\right)$. The lack of significant results in model 3 may be attributable to the lack of comparability of IPO firms' performance to well-established firms' performance. (Note 23) Overall, our results provide some support for the argument that high ability managers may be under more scrutiny during the IPO process and as a result behave less opportunistically in the IPO setting, which is consistent with our first hypothesis.

We note that our control variables are generally in the expected direction. We find that larger firms with higher asset intensity are associated with better earnings quality, and that firms that report negative earnings are associated with lower earnings quality. However, we find that more volatile cash flows and revenues are positively and often significantly associated with earnings quality for our IPO sample; whereas, we would generally expect firms with more volatile cash flows and revenues to have poor earnings quality. This exception may be because IPO firms generally experience significant growth leading up to their IPO, and thus higher levels of volatility may be perceived as an indicator of future growth potential for IPO firms. In addition, we find that firms with longer operating cycles are associated with better earnings quality, which is contrary to our expectations. We also believe that this exception can be attributed to the IPO setting given that a longer operating cycle provides more information about the operations of IPO firms, thus reducing the information asymmetry between management and outside investors with access to limited information about the firm.

\subsection{Manager Ability and IPO Underpricing}

We use equation (8), to estimate the effects of manager ability on IPO underpricing. The primary variables of interest in the models are the manager ability measures, MA-Score $\left(\right.$ Ability $\left._{1}\right)$, CEO compensation $\left(\right.$ Ability $\left._{2}\right)$, and CEO tenure $\left(\right.$ Ability $_{3}$ ). In Table 5, we include three models and apply ordinary least square (OLS) regression of equation (8). (Note 24) Model 1 measures manager ability using MA-Score (Ability $)_{1}$ ) developed by Demerjian et al. (2012), model 2 measures manager ability as CEO compensation (Ability $)_{2}$, and model 3 measures manager ability as CEO tenure (Ability $)_{3}$.

In model 1 , manager ability is significantly and negatively related to IPO underpricing $\left(\right.$ Ability $_{l}=-0.036$, $\mathrm{p}$-value $=$ 0.002). We also find significant negative relationships between manager ability and IPO underpricing in models 2 and 3 (Ability $_{2}=-0.026$, p-value $=0.058 ;$ Ability $_{3}=-0.005$, $\mathrm{p}$-value $\left.=0.019\right)$. Our findings are consistent with our second hypothesis and support the argument that that CEO ability enhances the credibility and reliability of management's financial reporting. As a result, high ability managers may have more bargaining power in the determination of the IPO offer price, resulting in less underpricing. As such, manager ability appears to be an important determinant of the level of proceeds received during an IPO. However, given the significant reduction in sample size in our CEO compensation and tenure models, our results should be interpreted with some caution, but taken as evidence that a relationship does exist between manager ability and IPO underpricing.

We also find that, in general, the directions of our control variables are consistent with prior literature. Integer offer price (Intpdummy) and price update (Priceupdate) are significantly positively associated with IPO underpricing, which is consistent with Bradley et al. (2004). These positive relationships are also consistent with more information asymmetry between firm insiders and outsiders given that integer offer prices and price updates imply a lack of certainty in the valuation of a security. High technology firms (Hightech) are positively associated with IPO underpricing, consistent with prior literature that indicates high technology IPOs tend to have higher IPO underpricing. The operations and/or business models of high-tech firms may be more difficult for potential investors to understand, leading to more information asymmetry. IPOs listed on renowned stock exchanges (NYSEAMEX) and with a longer history in the market (lnage) tend to have lower IPO underpricing. Engaging a high-quality auditor for an IPO (Topauditor) is negatively associated with IPO underpricing, which is consistent with signaling theory in that an association with top auditors sends positive signals to the market. Prior literature suggests that large audit firms have higher audit quality, thus reducing the level of information asymmetry between firm insiders and outsiders. IPOs backed by venture capitalists tend to have higher IPO underpricing, which is consistent with Barry, Muscarella, Peavy, \& Vetsuypens (1990). IPOs underwritten by top investment banks tend to have higher IPO underpricing, which is consistent with Loughran \& Ritter's (2004) reverse certification argument. This relationship suggests that investors perceive prestigious underwriters as less reliable given the role of these banks in many financial market bubbles. Thus, the lack of transparency on the part of the underwriter may contribute to perceived information asymmetry between the firm and outside investors. Finally, IPOs that have more assets before the offering tend to 
have lower IPO underpricing.

Table 5. Manager Ability and IPO Underpricing

\begin{tabular}{|c|c|c|c|c|c|c|}
\hline & Model 1 & & Model 2 & & Model 3 & \\
\hline Abilityl & $\begin{array}{l}-0.036 \\
(-3.10)\end{array}$ & $* * *$ & & & & \\
\hline Ability 2 & & & $\begin{array}{l}-0.026 \\
(-1.89)\end{array}$ & $*$ & & \\
\hline Ability 3 & & & & & $\begin{array}{l}-0.005 \\
(-2.34)\end{array}$ & $* * *$ \\
\hline Intpdummy & $\begin{array}{l}0.033 \\
(3.14)\end{array}$ & $* * *$ & $\begin{array}{l}0.049 \\
(2.75)\end{array}$ & $* * *$ & $\begin{array}{l}0.047 \\
(3.45)\end{array}$ & $* * *$ \\
\hline NYSEAMEX & $\begin{array}{l}-0.052 \\
(-1.97)\end{array}$ & $* *$ & $\begin{array}{l}-0.067 \\
(-2.42)\end{array}$ & $* *$ & $\begin{array}{l}-0.070 \\
(-1.64)\end{array}$ & \\
\hline Hightech & $\begin{array}{l}0.039 \\
(3.36)\end{array}$ & $* * *$ & $\begin{array}{l}-0.015 \\
(-0.76)\end{array}$ & & $\begin{array}{l}-0.012 \\
(-0.56)\end{array}$ & \\
\hline Topauditor & $\begin{array}{l}-0.027 \\
(-1.78)\end{array}$ & $*$ & $\begin{array}{l}-0.040 \\
(-1.80)\end{array}$ & $*$ & $\begin{array}{l}-0.038 \\
(-3.57)\end{array}$ & $* * *$ \\
\hline$V C$ & $\begin{array}{l}0.034 \\
(5.59)\end{array}$ & $* * *$ & $\begin{array}{l}0.065 \\
(2.11)\end{array}$ & $* *$ & $\begin{array}{l}0.066 \\
(6.82)\end{array}$ & $* * *$ \\
\hline Priceupdate & $\begin{array}{l}0.644 \\
(10.89)\end{array}$ & $* * *$ & $\begin{array}{l}0.702 \\
(7.13)\end{array}$ & $* * *$ & $\begin{array}{l}0.716 \\
(17.10)\end{array}$ & $* * *$ \\
\hline Lnprcd & $\begin{array}{l}0.064 \\
(5.53)\end{array}$ & $* * *$ & $\begin{array}{l}0.073 \\
(2.46)\end{array}$ & $* *$ & $\begin{array}{l}0.073 \\
(2.03)\end{array}$ & $* *$ \\
\hline Pureprimary & $\begin{array}{l}0.058 \\
(2.52)\end{array}$ & $* *$ & $\begin{array}{l}0.086 \\
(3.51)\end{array}$ & $* * *$ & $\begin{array}{l}0.086 \\
(8.16)\end{array}$ & $* * *$ \\
\hline Lnage & $\begin{array}{l}-0.018 \\
(-3.86)\end{array}$ & $* * *$ & $\begin{array}{l}-0.008 \\
(-0.68)\end{array}$ & & $\begin{array}{l}-0.010 \\
(-1.08)\end{array}$ & \\
\hline Topunderwriter & $\begin{array}{l}0.023 \\
(1.47)\end{array}$ & & $\begin{array}{l}0.067 \\
(2.54)\end{array}$ & $* *$ & $\begin{array}{l}0.066 \\
(2.17)\end{array}$ & $* *$ \\
\hline$B M$ & $\begin{array}{l}0.000 \\
(2.34)\end{array}$ & $* *$ & $\begin{array}{l}0.000 \\
(2.03)\end{array}$ & $* *$ & $\begin{array}{l}0.000 \\
(1.57)\end{array}$ & \\
\hline Lnat & $\begin{array}{l}-0.015 \\
(-11.69)\end{array}$ & $* * *$ & $\begin{array}{l}-0.035 \\
(-2.96)\end{array}$ & $* * *$ & $\begin{array}{l}-0.039 \\
(-4.10)\end{array}$ & $* * *$ \\
\hline Crisis_Big & $\begin{array}{l}0.023 \\
(0.62)\end{array}$ & & $\begin{array}{l}-0.031 \\
(-0.36)\end{array}$ & & $\begin{array}{l}-0.040 \\
(-1.00)\end{array}$ & \\
\hline Industry Fixed Effect & Yes & & Yes & & Yes & \\
\hline Year Fixed Effect & Yes & & Yes & & Yes & \\
\hline Observations & 2,964 & & 575 & & 576 & \\
\hline Adjusted $R^{2}$ & 0.335 & & 0.339 & & 0.340 & \\
\hline
\end{tabular}

Note: This table reports the coefficient estimates from OLS regression of IPO underpricing on manager ability. Model 1 presents the results using MA-Score (Ability1) from Demerjian et al. (2012) as the manager ability measure, model 2 presents the results using CEO compensation (Ability2) as the manager ability measure, and model 3 presents the results using CEO tenure (Ability3) as the manager ability measure. We include industry and year fixed effects in each of the models. Robust $t$ statistics appear in parentheses and are adjusted for intra-firm correlation with clustered standard errors.

$*, * *, * * *$ Denote statistical significance at the 10 percent, 5 percent, and 1 percent levels, respectively. All variables are defined in Appendix A. 


\section{Sensitivity Analysis and Robustness Checks}

\subsection{IPO Underpricing and Manager Ability Controlling for Earnings Quality}

In addition to influencing financial reporting quality, firm managers also dictate the use of firm resources. According to Demerjian et al. (2012) an effective (high ability) manager should be more efficient in transforming resources to revenue relative to their industry peers. Specifically, higher ability managers should be able to generate higher revenue for a given level of resources, or minimize the resources used to generate a given level of revenue (Demerjian et al., 2012). The ability to allocate resources is particularly relevant in an IPO setting because IPOs result in an influx of available capital for firm investment. As such, IPO underpricing is suboptimal for high ability managers that can efficiently and effectively manage firm resources and they should place greater value on the availability of capital to fund future growth. Chemmanur and Paeglis (2005) also suggest that better managers are likely to select better projects and implement them more effectively than low ability managers. Additionally, Leverty and Grace (2012) find that manager ability is negatively associated with the amount of time a firm spends in distress and the likelihood of firm failure. These studies suggest that manager ability should contribute to better overall firm performance during and after an IPO.

Given that high ability managers directly influence resource management (Demerjian et al., 2012; Demerjian et al., 2013), the presence of high ability managers at IPO firms may serve as a signal to the market of the firm's overall quality. Thus, in addition to their indirect effect on IPO underpricing via their influence on the financial reporting process, we should also expect manager ability to have a more direct influence on IPO underpricing via their superior ability to manage firm resources. In Table 6 , we test the relation between manager ability and IPO underpricing after controlling for earnings quality. For this analysis we use only our primary manager ability measure from Demerjian (2012), MA-Score (Ability $)_{1}$.

Table 6 presents the results of examining the relationship between manager ability and IPO underpricing controlling for earnings quality using ordinary least square (OLS) regression of equation (8). In model 1 earnings quality is measured using the Jones (1991) model $\left(E Q_{1}\right)$, model 2 measures earnings quality using the modified Jones (1991) model $\left(E Q_{2}\right)$ (Dechow et al., 1995), model 3 measures earnings quality using discretionary accruals controlling for ROA $\left(E Q_{3}\right)$ (Kothari et al., 2005), and model 4 measures earnings quality using our aggregate measure (AggreEQ).

We find that manager ability continues to be significantly and negatively associated with IPO underpricing even after controlling for earnings quality in all model specifications. Our results demonstrate that the influence of manager ability on IPO underpricing extends beyond the manager's influence on financial reporting. This suggests that the manager ability measure also captures other factors that contribute to the manager's performance, such as efficient resource allocation, investment in value maximizing projects, and/or superior operational and industry knowledge (Demerjian et al., 2012).

\subsection{Manager Ability and IPO Proceeds}

Given the propensity for high ability managers to select better projects and implement them more effectively than low ability managers (Chemmanur \& Paeglis, 2005), we should expect these managers to value the availability of investable capital relative to their lower ability counterparts. As such, it is in the best interest of high ability managers to minimize IPO underpricing to maximize the capital available to invest in future growth opportunities. Raising more proceeds during the IPO allows high ability managers to invest in value maximizing projects that spur firm growth, thus improving long-term firm performance and increasing firm value.

In Table 7, we investigate the relation between manager ability and IPO proceeds. We expect high ability managers to raise more funds during the IPO process to fund more positive NPV projects. The primary variable of interest in the model is manager ability measured by Demerjian et al. (2012), MA-Score (Ability). In Table 7, we include four models and apply ordinary least square (OLS) regression of the following model from DuCharme et al. (2001):

$$
\begin{aligned}
& \text { Lnprcd }=\beta_{0}+\beta_{1} \text { Ability }_{i}+\beta_{2} E Q_{i}+\beta_{3} U M A+\beta_{4} \text { Sgrowth }+\beta_{5} \text { Retained }+\beta_{6} V C \\
& +\beta_{7} \text { Topunderwriter }+\beta 8 \text { Lnat }+ \text { Industry and Year Fixed effects }+\varepsilon
\end{aligned}
$$

All variables used in this model are defined in Appendix A. In model 1 earnings quality $\left(E Q_{1}\right)$ is measured using the Jones (1991) model, model 2 measures earnings quality $\left(E Q_{2}\right)$ using the modified Jones (1991) model (Dechow et al., $1995)$, model 3 measures earnings quality $\left(E Q_{3}\right)$ using discretional accruals controlling for ROA (Kothari et al., 2005), and model 4 measures earnings quality using our aggregate measure (AggreEQ). 
Table 6. Relationship Between IPO Underpricing and Manager Ability, Controlling for Earnings Quality

\begin{tabular}{|c|c|c|c|c|c|c|c|c|}
\hline & Model 1 & & Model 2 & & Model 3 & & Model 4 & \\
\hline Abilityl & $\begin{array}{l}-0.037 \\
(-4.81)\end{array}$ & $* * *$ & $\begin{array}{l}-0.039 \\
(-4.78)\end{array}$ & $* * *$ & $\begin{array}{l}-0.037 \\
(-5.38)\end{array}$ & $* * *$ & $\begin{array}{l}-0.039 \\
(-4.89)\end{array}$ & $* * *$ \\
\hline$E Q 1$ & $\begin{array}{l}-0.013 \\
(-4.41)\end{array}$ & $* * *$ & & & & & & \\
\hline$E Q 2$ & & & $\begin{array}{l}-0.019 \\
(-2.78)\end{array}$ & $* * *$ & & & & \\
\hline$E Q 3$ & & & & & $\begin{array}{l}-0.024 \\
(-5.72)\end{array}$ & $* * *$ & & \\
\hline AggreEQ & & & & & & & $\begin{array}{l}-0.020 \\
(-3.46)\end{array}$ & $* * *$ \\
\hline Intpdummy & $\begin{array}{l}0.046 \\
(2.64)\end{array}$ & $* * *$ & $\begin{array}{l}0.047 \\
(2.72)\end{array}$ & $* * *$ & $\begin{array}{l}0.047 \\
(2.65)\end{array}$ & $* * *$ & $\begin{array}{l}0.047 \\
(2.68)\end{array}$ & $* * *$ \\
\hline NYSEAMEX & $\begin{array}{l}-0.050 \\
(-1.49)\end{array}$ & & $\begin{array}{l}-0.049 \\
(-1.47)\end{array}$ & & $\begin{array}{l}-0.050 \\
(-1.50)\end{array}$ & & $\begin{array}{l}-0.049 \\
(-1.47)\end{array}$ & \\
\hline Hightech & $\begin{array}{l}0.046 \\
(5.46)\end{array}$ & $* * *$ & $\begin{array}{l}0.046 \\
(5.72)\end{array}$ & $* * *$ & $\begin{array}{l}0.045 \\
(5.74)\end{array}$ & $* * *$ & $\begin{array}{l}0.046 \\
(5.68)\end{array}$ & $* * *$ \\
\hline Topauditor & $\begin{array}{l}-0.012 \\
(-1.80)\end{array}$ & $*$ & $\begin{array}{l}-0.013 \\
(-1.69)\end{array}$ & $*$ & $\begin{array}{l}-0.019 \\
(-1.80)\end{array}$ & $*$ & $\begin{array}{l}-0.013 \\
(-1.74)\end{array}$ & $*$ \\
\hline$V C$ & $\begin{array}{l}0.046 \\
(12.88)\end{array}$ & $* * *$ & $\begin{array}{l}0.047 \\
(15.34)\end{array}$ & $* * *$ & $\begin{array}{l}0.047 \\
(14.82)\end{array}$ & $* * *$ & $\begin{array}{l}0.047 \\
(14.34)\end{array}$ & $* * *$ \\
\hline Priceupdate & $\begin{array}{l}0.695 \\
(6.76)\end{array}$ & $* * *$ & $\begin{array}{l}0.693 \\
(6.70)\end{array}$ & $* * *$ & $\begin{array}{l}0.695 \\
(6.67)\end{array}$ & $* * *$ & $\begin{array}{l}0.695 \\
(6.69)\end{array}$ & $* * *$ \\
\hline Lnprcd & $\begin{array}{l}0.064 \\
(4.18)\end{array}$ & $* * *$ & $\begin{array}{l}0.063 \\
(4.27)\end{array}$ & $* * *$ & $\begin{array}{l}0.063 \\
(4.13)\end{array}$ & $* * *$ & $\begin{array}{l}0.063 \\
(4.21)\end{array}$ & $* * *$ \\
\hline Pureprimary & $\begin{array}{l}0.070 \\
(2.35)\end{array}$ & $* *$ & $\begin{array}{l}0.069 \\
(2.38)\end{array}$ & $* *$ & $\begin{array}{l}0.069 \\
(2.31)\end{array}$ & $* *$ & $\begin{array}{l}0.069 \\
(2.35)\end{array}$ & $* *$ \\
\hline Lnage & $\begin{array}{l}-0.012 \\
(-9.03)\end{array}$ & $* * *$ & $\begin{array}{l}-0.012 \\
(-7.02)\end{array}$ & $* * *$ & $\begin{array}{l}-0.011 \\
(-6.69)\end{array}$ & $* * *$ & $\begin{array}{l}-0.012 \\
(-7.12)\end{array}$ & $* * *$ \\
\hline Topunderwriter & $\begin{array}{l}0.034 \\
(5.20)\end{array}$ & $* * *$ & $\begin{array}{l}0.034 \\
(5.11)\end{array}$ & $* * *$ & $\begin{array}{l}0.035 \\
(5.27)\end{array}$ & $* * *$ & $\begin{array}{l}0.034 \\
(5.21)\end{array}$ & $* * *$ \\
\hline$B M$ & $\begin{array}{l}0.000 \\
(4.46)\end{array}$ & $* * *$ & $\begin{array}{l}0.000 \\
(4.20)\end{array}$ & $* * *$ & $\begin{array}{l}0.000 \\
(4.37)\end{array}$ & $* * *$ & $\begin{array}{l}0.000 \\
(4.25)\end{array}$ & $* * *$ \\
\hline Lnat & $\begin{array}{l}-0.012 \\
(-1.87)\end{array}$ & $*$ & $\begin{array}{l}-0.012 \\
(-1.86)\end{array}$ & $*$ & $\begin{array}{l}-0.012 \\
(-1.77)\end{array}$ & $*$ & $\begin{array}{l}-0.012 \\
(-1.85)\end{array}$ & $*$ \\
\hline Crisis_Big & $\begin{array}{l}0.025 \\
(0.41)\end{array}$ & & $\begin{array}{l}0.025 \\
(0.41)\end{array}$ & & $\begin{array}{l}0.028 \\
(0.46)\end{array}$ & & $\begin{array}{l}0.026 \\
(0.42)\end{array}$ & \\
\hline Industry Fixed Effect & Yes & & Yes & & Yes & & Yes & \\
\hline Year Fixed Effect & Yes & & Yes & & Yes & & Yes & \\
\hline Observations & 2,072 & & 2,068 & & 2,068 & & 2,068 & \\
\hline Adjusted $R^{2}$ & 0.286 & & 0.288 & & 0.287 & & 0.287 & \\
\hline
\end{tabular}

Note: This table reports the coefficient estimates from OLS regression of IPO underpricing earnings on manager ability controlling for earnings quality. Model 1 presents the results using the Jones (1991) model $\left(E Q_{1}\right)$ as the earnings quality measure, model 2 presents the results using the modified Jones (1991) model $\left(E Q_{2}\right)$ based on Dechow et al. (1995) as the earnings quality measure, model 3 presents the results using discretionary accruals controlling for ROA $\left(E Q_{3}\right)$ based on Kothari et al. (2005) as the earnings quality measure, and model 4 presents the results using our aggregate earnings quality measure $($ AggreEQ). We include industry and year fixed effects in each of the models. Robust $t$ statistics appear in parentheses and are adjusted for intra-firm correlation with clustered standard errors.

$*, * *, * * *$ Denote statistical significance at the 10 percent, 5 percent, and 1 percent levels, respectively. All other variables are defined in Appendix A. 
Table 7. Manager Ability and IPO Proceeds.

\begin{tabular}{|c|c|c|c|c|c|c|c|c|}
\hline & Model 1 & & Model 2 & & Model 3 & & Model 4 & \\
\hline Abilityl & $\begin{array}{l}0.492 \\
(2.40)\end{array}$ & $* *$ & $\begin{array}{l}0.520 \\
(2.52)\end{array}$ & $* *$ & $\begin{array}{l}0.511 \\
(2.45)\end{array}$ & $* *$ & $\begin{array}{l}0.518 \\
(2.52)\end{array}$ & $* *$ \\
\hline$E Q 1$ & $\begin{array}{l}-0.009 \\
(-2.31)\end{array}$ & $* *$ & & & & & & \\
\hline$E Q 2$ & & & $\begin{array}{l}0.057 \\
(2.03)\end{array}$ & $* *$ & & & & \\
\hline EQ3 & & & & & $\begin{array}{l}0.035 \\
(0.68)\end{array}$ & & & \\
\hline AggreEQ & & & & & & & $\begin{array}{l}0.048 \\
(1.52)\end{array}$ & \\
\hline Stdcflow & $\begin{array}{l}0.231 \\
(1.92)\end{array}$ & $*$ & $\begin{array}{l}0.203 \\
(1.64)\end{array}$ & & $\begin{array}{l}0.210 \\
(1.62)\end{array}$ & & $\begin{array}{l}0.207 \\
(1.66)\end{array}$ & $*$ \\
\hline$U M A$ & $\begin{array}{l}-0.020 \\
(-1.22)\end{array}$ & & $\begin{array}{l}-0.060 \\
(-3.13)\end{array}$ & $* * *$ & $\begin{array}{l}-0.033 \\
(-2.85)\end{array}$ & $* * *$ & $\begin{array}{l}-0.046 \\
(-3.37)\end{array}$ & $* * *$ \\
\hline Sgrowth & $\begin{array}{l}-0.003 \\
(-0.90)\end{array}$ & & $\begin{array}{l}-0.002 \\
(-0.81)\end{array}$ & & $\begin{array}{l}-0.003 \\
(-0.84)\end{array}$ & & $\begin{array}{l}-0.002 \\
(-0.85)\end{array}$ & \\
\hline Retained & $\begin{array}{l}-0.001 \\
(-5.98)\end{array}$ & $* * *$ & $\begin{array}{l}-0.001 \\
(-6.11)\end{array}$ & $* * *$ & $\begin{array}{l}-0.001 \\
(-6.09)\end{array}$ & $* * *$ & $\begin{array}{l}-0.001 \\
(-5.97)\end{array}$ & $* * *$ \\
\hline$V C$ & $\begin{array}{l}-0.015 \\
(-0.20)\end{array}$ & & $\begin{array}{l}0.004 \\
(0.05)\end{array}$ & & $\begin{array}{l}-0.000 \\
(-0.00)\end{array}$ & & $\begin{array}{l}0.003 \\
(0.03)\end{array}$ & \\
\hline Topunderwriter & $\begin{array}{l}0.160 \\
(2.54)\end{array}$ & $* *$ & $\begin{array}{l}0.145 \\
(2.14)\end{array}$ & $* *$ & $\begin{array}{l}0.148 \\
(2.36)\end{array}$ & $* *$ & $\begin{array}{l}0.148 \\
(2.25)\end{array}$ & $* *$ \\
\hline Lnsize & $\begin{array}{l}0.458 \\
(16.91)\end{array}$ & $* * *$ & $\begin{array}{l}0.463 \\
(17.26)\end{array}$ & $* * *$ & $\begin{array}{l}0.461 \\
(16.45)\end{array}$ & $* * *$ & $\begin{array}{l}0.462 \\
(17.15)\end{array}$ & $* * *$ \\
\hline $\begin{array}{l}\text { Industry } \quad \text { Fixed } \\
\text { Effect }\end{array}$ & Yes & & Yes & & Yes & & Yes & \\
\hline Year Fixed Effect & Yes & & Yes & & Yes & & Yes & \\
\hline Observations & 489 & & 482 & & 482 & & 482 & \\
\hline Adjusted $R^{2}$ & 0.688 & & 0.682 & & 0.681 & & 0.681 & \\
\hline
\end{tabular}

Note: This table reports the coefficient estimates from OLS regression of IPO proceeds on manager ability. Model 1 presents the results using the Jones (1991) model $\left(E Q_{1}\right)$ as the earnings quality measure, model 2 presents the results using the modified Jones (1991) model $\left(E Q_{2}\right)$ based on Dechow et al. (1995) as the earnings quality measure, model 3 presents the results using discretionary accruals controlling for ROA $\left(E Q_{3}\right)$ based on Kothari et al. (2005) as the earnings quality measure, and model 4 presents the results using our aggregate earnings quality measure (AggreEQ). We include industry and year fixed effects in each of the models. Robust $t$ statistics appear in parentheses and are adjusted for intra-firm correlation with clustered standard errors.

$*, * *, * * *$ Denote statistical significance at the 10 percent, 5 percent, and 1 percent levels, respectively. All other variables are defined in Appendix A. 
We find evidence consistent with our expectation that high ability managers increase the proceeds raised during an IPO. Specifically, we find that manager ability is positively and significantly related to proceeds raised during the IPO across all the four models. Our results are consistent with the arguments that high ability managers view the IPO process as an opportunity to raise capital for future growth, and thus seek to avoid IPO underpricing. (Note 25)

\subsection{CEO Monitoring Incentives}

Several studies suggest that executive compensation influences the extent of IPO underpricing, and that more reputable managers receive higher compensation (Alavi et al., 2008; Bruton et al., 2010; Demerjian et al., 2012; Falato, Li, \& Milbourne, 2011; Graham, Harvey, \& Puri, 2013; Ljungqvist \& Wilhelm, 2003; McBain \& Krause, 1989; Pukthuanthong, Roll, \& Walker, 2007; Rajgopal, Shevlin, \& Zamora, 2006). Many IPO firms also impose an initial lock-up period requiring firm insiders to hold their shares for 180 days after the IPO prior to selling them (Field and Hanka, 2001). Field and Hanka (2001) suggest that the lock-up period serves several purposes including reassuring the market that key employees will continue to focus on firm performance and providing a credible signal that insiders are not attempting to cash out in advance of bad news. This suggests that the lock-up period is intended to reduce opportunistic behavior by eliminating the ability of firm insiders to sell their shares at the IPO. Additionally, Field and Hanka (2001) find that when lock-ups expire, executives and other shareholders sell less aggressively than venture capitalists, which implies that executives are more likely to be long term investors. 
Table 8. Effect of CEO Monitoring on the Relationship Between Manager Ability and IPO Underpricing.

\begin{tabular}{|c|c|c|c|c|c|c|}
\hline & Model 1 & & Model 2 & & Model 3 & \\
\hline Ability $_{1}$ & $\begin{array}{l}-0.007 \\
(-0.51)\end{array}$ & & & & & \\
\hline 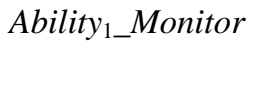 & $\begin{array}{l}-0.007 \\
(-2.32)\end{array}$ & $* *$ & & & & \\
\hline Ability $_{2}$ & & & $\begin{array}{l}-0.026 \\
(-0.55)\end{array}$ & & & \\
\hline Ability 2 Monitor & & & $\begin{array}{l}-0.052 \\
(-1.79)\end{array}$ & $*$ & & \\
\hline Ability $_{3}$ & & & & & $\begin{array}{l}-0.015 \\
(-0.98)\end{array}$ & \\
\hline Ability $_{3 \_}$Monitor & & & & & $\begin{array}{l}-0.017 \\
(-0.20)\end{array}$ & \\
\hline Monitor & $\begin{array}{l}-0.006 \\
(-0.46)\end{array}$ & & $\begin{array}{l}0.348 \\
(2.43)\end{array}$ & $* *$ & $\begin{array}{l}0.052 \\
(0.59)\end{array}$ & \\
\hline Intpdummy & $\begin{array}{l}0.017 \\
(0.36)\end{array}$ & & $\begin{array}{l}0.022 \\
(0.28)\end{array}$ & & $\begin{array}{l}0.018 \\
(0.20)\end{array}$ & \\
\hline NYSEAMEX & $\begin{array}{l}-0.054 \\
(-3.42)\end{array}$ & $* * *$ & $\begin{array}{l}-0.047 \\
(-5.34)\end{array}$ & $* * *$ & $\begin{array}{l}-0.050 \\
(-2.55)\end{array}$ & $* *$ \\
\hline Hightech & $\begin{array}{l}0.017 \\
(0.31)\end{array}$ & & $\begin{array}{l}-0.090 \\
(-14.32)\end{array}$ & $* * *$ & $\begin{array}{l}-0.070 \\
(-2.32)\end{array}$ & $* *$ \\
\hline Topauditor & $\begin{array}{l}-0.004 \\
(-2.43)\end{array}$ & $* *$ & $\begin{array}{l}-0.000 \\
(-0.01)\end{array}$ & & $\begin{array}{l}-0.047 \\
(-9.07)\end{array}$ & $* * *$ \\
\hline$V C$ & $\begin{array}{l}0.029 \\
(0.91)\end{array}$ & & $\begin{array}{l}0.033 \\
(1.35)\end{array}$ & & $\begin{array}{l}0.064 \\
(0.81)\end{array}$ & \\
\hline Priceupdate & $\begin{array}{l}0.763 \\
(1.88)\end{array}$ & $*$ & $\begin{array}{l}0.713 \\
(5.10)\end{array}$ & $* * *$ & $\begin{array}{l}0.790 \\
(4.15)\end{array}$ & $* * *$ \\
\hline Lnpred & $\begin{array}{l}0.030 \\
(2.07)\end{array}$ & $* *$ & $\begin{array}{l}0.016 \\
(0.58)\end{array}$ & & $\begin{array}{l}-0.005 \\
(-0.12)\end{array}$ & \\
\hline Pureprimary & $\begin{array}{l}0.040 \\
(2.10)\end{array}$ & $* *$ & $\begin{array}{l}0.043 \\
(1.52)\end{array}$ & & $\begin{array}{l}0.041 \\
(1.20)\end{array}$ & \\
\hline Lnage & $\begin{array}{l}0.000 \\
(0.02)\end{array}$ & & $\begin{array}{l}-0.003 \\
(-0.16)\end{array}$ & & $\begin{array}{l}0.019 \\
(6.04)\end{array}$ & $* * *$ \\
\hline Topunderwriter & $\begin{array}{l}0.010 \\
(0.50)\end{array}$ & & $\begin{array}{l}-0.003 \\
(-0.03)\end{array}$ & & $\begin{array}{l}0.009 \\
(0.08)\end{array}$ & \\
\hline$B M$ & $\begin{array}{l}0.000 \\
(5.17)\end{array}$ & $* * *$ & $\begin{array}{l}0.0000 \\
(0.34)\end{array}$ & & $\begin{array}{l}-0.000 \\
(-0.13)\end{array}$ & \\
\hline Lnat & $\begin{array}{l}-0.005 \\
(-0.46)\end{array}$ & & $\begin{array}{l}-0.023 \\
(-4.60)\end{array}$ & $* * *$ & $\begin{array}{l}-0.003 \\
(-0.20)\end{array}$ & \\
\hline Crisis_Big & $\begin{array}{l}-0.013 \\
(-0.28)\end{array}$ & & $\begin{array}{l}-0.053 \\
(-1.01)\end{array}$ & & $\begin{array}{l}0.019 \\
(0.41)\end{array}$ & \\
\hline
\end{tabular}


Table 8. (continued)

\begin{tabular}{|c|c|c|c|c|}
\hline & Model 1 & Model 2 & & Model 3 \\
\hline \multirow[t]{2}{*}{ Lnat } & -0.005 & -0.023 & $* * *$ & -0.003 \\
\hline & $(-0.46)$ & $(-4.60)$ & & $(-0.20)$ \\
\hline \multirow[t]{2}{*}{ Crisis_Big } & -0.013 & -0.053 & & 0.019 \\
\hline & $(-0.28)$ & $(-1.01)$ & & $(0.41)$ \\
\hline Industry fixed effect & Yes & Yes & & Yes \\
\hline Year fixed effect & Yes & Yes & & Yes \\
\hline Observations & 554 & 138 & & 118 \\
\hline Adjusted $R^{2}$ & 0.389 & 0.359 & & 0.319 \\
\hline
\end{tabular}

Note: This table reports the coefficient estimates from OLS regression of IPO underpricing on manager ability and CEO monitoring incentive. Model 1 presents the results using MA-Score (Ability $)_{1}$ from Demerjian et al. (2012) as the manager ability measure, model 2 presents the results using CEO compensation $\left(\right.$ Ability $_{2}$ ) as the manager ability measure, and model 3 presents the results using CEO tenure $\left(\right.$ Ability $\left._{3}\right)$ as the manager ability measure. We include industry and year fixed effects in each of the models. Robust $t$ statistics appear in parentheses and are adjusted for intra-firm correlation with clustered standard errors.

$*, * *, * * *$ Denote statistical significance at the 10 percent, 5 percent, and 1 percent levels, respectively. All variables are defined in Appendix A.

Raising more proceeds during the IPO allows high ability managers to invest in more value maximizing projects that spur firm growth, thus improving long-term firm performance and increasing firm value. If a high ability manager also receives equity-based compensation, increasing the value of the firm not only increases their future financial benefits, but also improves their career prospects. Improved long-term performance spurred by investing IPO proceeds could benefit high ability managers financially by increasing the share price presumably past the lockup-period. As such, we expect equity ownership to significantly influence the relationship between manager ability and IPO underpricing. Specifically, we expect high ability managers with higher equity ownership to have more incentive to monitor the IPO process, resulting in a reduction in IPO underpricing.

We use equation (8), to estimate the influence of CEO equity-based compensation on the relationship between manager ability and IPO underpricing. The primary variables of interest in the models are the interactions between each of the CEO motivation and manager ability measures, MA-Score (Ability ${ }_{1}$ Monitor), CEO compensation (Ability ${ }_{2}$ Monitor), and CEO tenure (Ability ${ }_{3}$ Monitor). We use an indicator variable and categorize CEOs' monitoring incentive (Monitor) as one if their ownership percentage is above the median value of CEO ownership percentage in the sample, and zero otherwise. (Note 26 and Note 27) In Table 8, we include three models and apply OLS regression of equation (8). Model 1 measures manager ability using MA-Score (Ability $)_{1}$ developed by Demerjian et al. (2012), model 2 measures manager ability as CEO compensation (Ability $)_{2}$, and model 3 measures manager ability as CEO tenure (Ability $)_{3}$.

In model 1, the interaction term between manager ability and CEO motivation (Ability ${ }_{I_{-}}$Monitor) is negative and significant $\left(\right.$ Ability $_{I_{-}}$Monitor $_{=}-0.007, \mathrm{p}$-value $\left.=0.020\right)$. We also find a significant negative relationship between the interaction term and IPO underpricing in model 2 (Ability Monitor $_{2}-0.052$, p-value $=0.073$ ), which suggests that high manager ability reduces IPO underpricing more significantly if the CEO has an incentive to act as a monitor. In

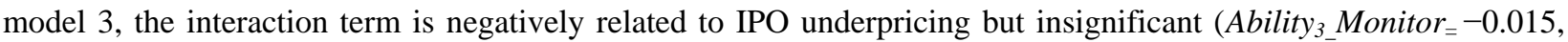
p-value $=0.33)$. However, in each model we find that the interaction between manager ability and CEO monitoring motivation has the same sign as the manager ability variable, suggesting that the effect of manager ability on IPO underpricing becomes more pronounced when CEOs have a higher motivation to monitor the IPO process. Overall, our results suggest that CEO equity ownership does influence the relationship between manager ability and IPO underpricing; however, the strength of that relationship is tenuous. We also note that our results should be interpreted with caution given the significant reduction in sample size. 


\subsection{Additional Analyses}

We also perform several additional tests of the robustness of our results. First, several observations in SDC do not have information about total assets or the book-to-market ratio. To include these two variables in our main empirical analysis, we reduced our sample size from 3,909 to 2,964 IPO observations. As a part of our sensitivity analysis we re-perform our empirical model without using these two variables and found that our results were qualitatively the same.

In our main analysis, we constrain our sample to observations with manager ability proxies available one year prior to the IPO. As a robustness check, we relax this sample selection requirement, and re-examined our hypotheses by including observations without manager ability proxies available one year prior to the IPO. In this test we use the first available observation of the manager ability proxies within the databases, in doing so we assume that manager ability in general is the same or similar pre- and post-IPO. Removal of this restriction from our sample selection procedures increase our sample size from 2,964 to 4,153 IPO observations, and our results remained qualitatively the same. We also replace the continuous measure of MA-Score developed by Demerjian et al. (2012) with the ranked value used in other studies (Demerjian et al., 2013). Again, we find that our results remained qualitatively the same. Finally, we use alternative industry classification metrics, truncated the sample at the one percent level and winsorized the data at the three percent level, and again find that our main results were qualitatively the same.

\section{Conclusion}

This study examines the relationship between IPO underpricing, prospectus earnings quality, and manager ability. We find that manager ability is positively associated with three of our four earnings quality measures, and that all of our manager ability measures are associated with lower IPO underpricing after controlling for other firm characteristics known to affect IPO underpricing. We also find preliminary evidence that equity ownership strengthens the relationship between manager ability and IPO underpricing. Our results are robust to several factors including alternative sample selection criteria and control variables. Overall, our findings suggest that manager ability influences the outcome of an IPO.

Our study expands the body of literature examining the role of human capital in the IPO process and contributes to the literature in several ways. First, we extend the findings of Chemmanur and Paeglis (2005) by providing evidence that high ability managers influence IPO underpricing through their impact on the quality of earnings presented in the IPO prospectus. Our findings are also consistent with high ability managers behaving less opportunistically in the IPO setting because they are under more scrutiny during the IPO process. Second, we find that the relationship between manager ability and IPO underpricing is not mitigated when controlling for earnings quality, which suggests that managers influence IPO underpricing beyond their impact on financial reporting. Finally, we find preliminary evidence that equity ownership strengthens the relationship between manager ability and IPO underpricing, suggesting that CEOs with high levels of equity-based compensation more actively monitor the IPO process.

We also recognize the overall limitations of our findings; specifically, given our limited sample size, our results may not be generalizable to all IPO firms. However, in our analysis we attempt to address this issue by comparing our sample distribution and results to those of similar studies. Overall, we find that our sample distribution is comparable to prior literature and that our control variables also tend to behave normally. In addition, we also remove some sample selection criteria that limit our sample size in our robustness tests and find that our results remain qualitatively the same with the increased sample size. Finally, we note that the average explanatory power of our IPO underpricing models is around 33 percent, which is comparable to prior literature (Bajo \& Raimondo 2017; Butler et al., 2014; Zalata \& Roberts, 2016). However, it also implies that a significant amount of information asymmetry exists in the IPO market. Although our results suggest that manager ability contributes to a reduction in information asymmetry, future research should continue to examine additional explanations for the IPO underpricing phenomenon. The findings of this study should be useful to issuing firms considering hiring higher caliber managers, investors in evaluating IPO firms, and researchers interested in the impact of human capital on IPO underpricing.

\section{References}

Abernathy, J.L., Kubick, T., \& Masli, A. (2015). Managerial ability, financial reporting, and information asymmetry. Working Paper, Kennesaw State University, and the University of Kansas.

Aboody, D., Hughes, J., \& Liu, J. (2005). Earnings quality, insider trading, and cost of capital. Journal of Accounting Research, 43(5), 651-673. https://doi.org/10.1111/j.1475-679X.2005.00185.x

Akerlof, G.A. (1970). The market for "lemons": Quality uncertainty and the market mechanism. The Quarterly Journal of Economics, 84(3), 488-500. https://doi.org/10.2307/1879431 
Alavi, A., Pham, P.K., \& Pham.T.M. (2008). Pre-IPO ownership structure and its impact on the IPO process. Journal of Banking and Finance, 32(11), 2361-2375. https://doi.org/10.1016/j.jbankfin.2007.12.030

Ali, A., \& Zhang, W. (2015). CEO tenure and earnings management. Journal of Accounting and Economics, 59(1), 60-79. https://doi.org/10.1016/j.jacceco.2014.11.004

Armstrong C., G. Foster, D. Taylor, 2016. Abnormal accruals in newly public companies: Opportunistic misreporting or economic activity? Management Science, 62, 1316-1338. https://doi.org/10.1287/mnsc.2015.2179

Baatwah, S., Salleh, Z., \& Ahmad, N. (2015). Corporate governance mechanisms and audit report timeliness: Empirical evidence from Oman. International Journal of Accounting, Auditing, and Performance Evaluation, 11(3/4), 312-337. https://doi.org/10.1504/IJAAPE.2015.071580

Baik, B., Farber, D.B., \& Lee, S. (2011). CEO ability and management earnings forecasts. Contemporary Accounting Research, 28(5), 1645-1668. https://doi.org/10.1111/j.1911-3846.2011.01091.x

Ball, R. \& Shivakumar, L. (2008). Earnings quality at initial public offerings. Journal of Accounting and Economics, 45(2-3), 324-349. https://doi.org/10.1016/j.jacceco.2007.12.001

Barry, C., Muscarella, C., Peavy, H., \& Vetsuypens, M. (1990). The role of venture capital in the creation of public companies: Evidence from the going public process. Journal of Financial Economics, 27(2), 447-476. https://doi.org/10.1016/0304-405X(90)90064-7

Beatty, R., \& Ritter, J. (1986). Investment banking, reputation, and the underpricing of initial public offerings. Journal of Financial Economics, 15(1-2), 213-232. https://doi.org/10.1016/0304-405X(86)90055-3

Beber, A., \& Fabbri, D. (2012). Who times the foreign exchange market? Corporate speculation and CEO characteristics. Journal of Corporate Finance, 18(5), 1065-1087. https://doi.org/10.1016/j.jcorpfin.2012.07.004

Bergh, D. D., Connelly, B. L., Ketchen, D. J., \& Shannon, L. M. (2014). Signaling theory and equilibrium in strategic management research: an assessment and a research agenda. Journal of Management Studies, 51(8), 1334-60. https://doi.org/10.1111/joms.12097

Bhabra, H.S., \& Pettway, R.H. (2003). IPO prospectus information and subsequent performance. The Financial Review, 38(2003), 369-397. https://doi.org/10.1111/1540-6288.00051

Bhagat, S., Bolton, B., \& Subramanian, A. (2011). Manager Characteristics and Capital Structure: Theory and Evidence. Journal of Financial and Quantitative Analysis, 46(6), 1581-1627. https://doi.org/10.1017/S0022109011000482

Boulton, T.J., Smart, S.B., \& Zutter, C.J. (2011). Earnings quality and international IPO Underpricing. The Accounting Review, 86(2), 483-505. https://doi.org/10.2308/accr.00000018

Bradley, D.J., Cooney Jr., J.W., Jordan, B.D., \& Singh, A.K. (2004). Negotiation and the IPO offer price: A comparison of integer vs. non-integer IPOs. Journal of Financial and Quantitative Analysis, 39(3), 517-540. https://doi.org/10.1017/S0022109000004014

Brau, J.C., \& Johnson, P.M. (2009). Earnings management in IPOs: Post-engagement third party mitigation or issuer signaling? Advances in Accounting, incorporating Advances in International Accounting, 25(2), 125-135. https://doi.org/10.1016/j.adiac.2009.03.003

Bruton, G.D., Filatotchev, I., Chahine, S., \& Wright, M. (2010). Governance, Ownership Structure, and Performance of IPO Firms: The Impact of Different Types of Private Equity Investors and Institutional Environments. Strategic Management Journal, 31(5), 491-509.

Butler, A.W., O'Connor Keefe, M., \& Kieschnick, R. (2014). Robust determinants of IPO underpricing and their implications for IPO research. Journal of Corporate Finance, 27(2014), 367-383. https://doi.org/10.1016/j.jcorpfin.2014.06.002

Carter, R., \& Manaster, S. (1990). Initial public offerings and underwriter reputation. Journal of Finance, 45(4), 1045-1067. https://doi.org/10.1111/j.1540-6261.1990.tb02426.x

Castaner, X., \& Kavadis, N. (2013). Does good corporate governance prevent bad strategy? A study of corporate governance, financial diversification, and value creation by French corporations, 2000-2006. Strategic Management Journal, 34(7), 863-876. https://doi.org/10.1002/smj.2040

Chemmanur, T.J., \& Paeglis, I. (2005). Management quality, certification, and initial public offerings. Journal of Financial Economics, 76(2005), 331-368. https://doi.org/10.1016/j.jfineco.2004.10.001 
Cheng, Q., \& Warfield, T. (2005). Equity incentives and earnings management. The Accounting Review, 80(2), 441-476. https://doi.org/10.2308/accr.2005.80.2.441

Cheng, Q., Warfield, T., \& Ye, M. (2011). Equity incentives and earnings management: Evidence from the banking industry. Journal of Accounting, Auditing, and Finance, 26(2), 317-349. https://doi.org/10.1177/0148558X11401219

Cheung, K.T.S., Naidu, D., Navissi, F., \& Ranjeeni, K. (2017). Valuing talent: Do CEOs' ability and discretion unambiguously increase firm performance. Journal of Corporate Finance, 42(2017), 15-35. https://doi.org/10.1016/j.jcorpfin.2016.11.006

Chung, K.H., \& Zhang, G. (2011). Corporate governance and institutional ownership. The Journal of Financial and Quantitative Analysis, 46, 247-273. https://doi.org/10.1017/S0022109010000682

Cohen, B.D., \& Dean, T.J. (2005). Information asymmetry and investor valuation of IPOs: Top management team legitimacy as a capital market signal. Strategic Management Journal, 26(7), 683-690. https://doi.org/10.1002/smj.463

Dechow, P., Sloan, R., \& Sweeney, A. (1995). Detecting earnings management. The Accounting Review, 70, 193-225.

Dechow, P., W., Ge, \& Schrand, C. (2010). Understanding earnings quality: A review of the proxies, their determinants and their consequences. Journal of Accounting and Economics, 50(2-3), 344-401. https://doi.org/10.1016/j.jacceco.2010.09.001

Dellaportas, S. (2013). Conversations with inmate accountants: Motivation, opportunity and the fraud triangle. Accounting Forum, 37(2013), 29-39. https://doi.org/10.1016/j.accfor.2012.09.003

Demerjian, P.R., Lev, B., \& McVay, S.E. (2012). Quantifying managerial ability: A new measure and validity tests. Management Science, 58(7), 1229-1248. https://doi.org/10.1287/mnsc.1110.1487

Demerjian, P.R., Lev, B., Lewis, M.F., \& McVay, S.E. (2013). Managerial ability and earnings quality. The Accounting Review, 88(2), 463-498. https://doi.org/10.2308/accr-50318

Demerjian, P.R., Lewis, M., \& McVay, S.E. (2016). Managerial ability and earnings management. Working Paper, Emory University, University of Utah, and University of Washington.

DuCharme, L.L., Malatesta, P.H., \& Sefcik, S.E. (2001). Earnings management: IPO valuation and subsequent performance. Journal of Accounting, Auditing, and Finance, 16(4), 369-396. https://doi.org/10.1177/0148558X0101600409

Ertimur, Y., E. Sletten and J. Sunder, 2014. Large Shareholders and Disclosure Strategies: Evidence from IPO Lockup Expirations. Journal of Accounting and Economics, 58, 79-95. https://doi.org/10.1016/j.jacceco.2014.06.002

Falato, A., Li, D., \& Milbourne, T. (2012). Which skills matter in the market for CEOs? Evidence from pay for CEO credentials. Working Paper, Federal Reserve Board and Washington University in St. Louis.

Field, L.C., \& Hanka, G. (2001). The expiration of IPO share lockups. The Journal of Finance, 56(2), 471-500. https://doi.org/10.1111/0022-1082.00334

Francis, J., Huang, A.H., Rajgopal, S., \& Zang, A. (2008). CEO reputation and earnings quality. Contemporary Accounting Research, 25(1), 109-147. https://doi.org/10.1506/car.25.1.4

Francis, J., Nanda, D., \& Olsson, P. (2008). Voluntary disclosure, earnings quality, and cost of capital. Journal of Accounting Research, 46(1), 53-99. https://doi.org/10.1111/j.1475-679X.2008.00267.x

Frank, D.H., \& Obloj, T. (2013). Firm-specific human capital, organizational incentives, and agency costs: Evidence from retail banking. Strategic Management Journal, 35(9), 1279-1301. https://doi.org/10.1002/smj.2148

Graham, J.R., Harvey, C.R., \& Puri, M. (2013). Managerial attitudes and corporate actions. Journal of Financial Economics, 109(1), 103-121. https://doi.org/10.1016/j.jfineco.2013.01.010

Grant, J., Markarian, G., \& Parbonetti, A. (2009). CEO risk-related incentives and income smoothing. Contemporary Accounting Research, 26(4), 1029-1065. https://doi.org/10.1506/car.26.4.2

Green, T.C., \& Hwang, B.H. (2011). Initial public offerings as lotteries: Skewness preference and first-day returns. 
Management Science, 57(3), 432-444.

Gul, F.A., Khedmati, M., Lim, E.K., \& Navissi, F. (2018). Managerial ability, financial distress, and audit fees. Accounting Horizons, 32(1), 29-51. https://doi.org/10.2308/acch-51888

Hribar, P., and C. Nichols. 2007. The use of unsigned earnings quality measures in tests of earnings management. Journal of Accounting Research, 45(5), 1017-1053. https://doi.org/10.1111/j.1475-679X.2007.00259.x

Iqbal, Z. (2015). CEO age, education, and introduction of hedging in the oil and gas industry. Journal of Economics and Finance, 39(1), 189-200. https://doi.org/10.1007/s12197-013-9274-y

Jackson, S.B., Wilcox, E., \& Strong, J.M. (2002). Do initial public offering firms understate the allowance for bad debts? Advances in Accounting, 19(2002), 89-118. https://doi.org/10.1016/S0882-6110(02)19006-7

Jensen, M., \& Meckling, W. (1976). Theory of the firm: Managerial behavior, agency costs and ownership structure. Journal of Financial Economics, 3(4), 305-360. https://doi.org/10.1016/0304-405X(76)90026-X

Jenter, D., \& Kanaan, F. (2015). CEO turnover and relative performance evaluation. The Journal of Finance, 70(5), 2155-2183. https://doi.org/10.1111/jofi.12282

Jones, J. (1991). Earnings management during import relief investigations. Journal of Accounting Research, 29, 193-228. https://doi.org/10.2307/2491047

Kothari, S., Leone, A., and Wasley, C. (2005), Performance matched discretionary accrual measures. Journal of Accounting and Economics, 39, 163-197. https://doi.org/10.1016/j.jacceco.2004.11.002

Krishnan, G.V., \& Wang, C. (2015). The relation between managerial ability and audit fees and going concern opinions. Auditing: A Journal of Practice and Theory, 34(3), 139-160.https://doi.org/10.2308/ajpt-50985

Leone, A. J., Rock, S., \& Willenborg, M. (2007). Disclosure of intended use of proceeds and underpricing. Journal of Accounting Research, 45(1), 111-153. https://doi.org/10.1111/j.1475-679X.2007.00229.x

Leverty, J.T., \& Grace, M.F. Dupes or incompetents? An examination of management's impact on firm distress. The Journal of Risk and Insurance, 79(3), 751-783. https://doi.org/10.1111/j.1539-6975.2011.01443.x

Li, C., Sun, L., \& Ettredge, M. (2010). Financial executive qualifications, financial executive turnover, and adverse SOX 404 opinions. Journal of Accounting and Economics, 50(1), 93-110. https://doi.org/10.1016/j.jacceco.2010.01.003

Ljungqvist, A. \& Wilhelm Jr., W. (2003). IPO pricing in the dot-com bubble. The Journal of Finance, 58(2), $723-752$. https://doi.org/10.1111/1540-6261.00543

Ljungqvist, A.P. (2007). IPO underpricing. In Handbook of Corporate Finance, Volume 1: Empirical Corporate Finance, edited by E. Eckbo, 375-422. New York, NY: Elsevier/North Holland. https://doi.org/10.1016/B978-0-444-53265-7.50021-4

Lowry, M., \& Murphy, K.J. (2007). Executive stock options and IPO underpricing. Journal of Financial Economics, 85(1), 39-65. https://doi.org/10.1016/j.jfineco.2006.05.006

Lowry, M., Officer, M.S., \& Schwert, G.W. (2010). The variability of IPO initial returns. Journal of Finance, 65(3), 309-335. https://doi.org/10.1111/j.1540-6261.2009.01540.x

Mande, V., \& Son, M. (2012). CEO Centrality and Meeting or Beating Analysts' Earnings Forecasts. Journal of Business Finance and Accounting, 39(1) \& (2), 82-112. https://doi.org/10.1111/j.1468-5957.2011.02262.X

McBain, M.L. \& Krause, D.S. (1989). Going public: The impact of insiders' holding on the price of initial public offerings. Journal of Business Venturing, 4(4), 419-428. https://doi.org/10.1016/0883-9026(89)90011-6

Naiker, V., \& Sharma, D. S. (2009). Former Audit Partners on the Audit Committee and Internal Control Deficiencies. Accounting Review, 84(2),559-587. https://doi.org/10.2308/accr.2009.84.2.559

O’Brien, P.C., \& Bhushan, R. (1990). Analyst following and institutional ownership. Journal of Accounting Research, 28, 55-76. https://doi.org/10.2307/2491247

Olsen, B., Sisodiya, S.R., \& Swisher, J. (2016). A note on assessing the relation between CEO characteristics and stock performance: Alpha above replacement. Accounting and Finance, 56(3), 787-802. https://doi.org/10.1111/acfi.12095

Park, H.D., \& Patel, P.C. (2015). How does ambiguity influence IPO underpricing? The role of the signaling environment. Journal of Management Studies, 52(6), 796-818. https://doi.org/10.1111/joms.12132 
Pukthuanthong, K., Roll, R., \& Walker, T. (2007). How employee stock options and executive equity ownership affect long-term IPO operating performance. Journal of Corporate Finance, 13(5) 695-720. https://doi.org/10.1016/j.jcorpfin.2007.02.003

Rajgopal, S., Shevlin, T., \& Zamora, V. (2006). CEO's outside employment opportunities and the lack of relative performance in compensation contracts. The Journal of Finance, 61(4), 1813-1844. https://doi.org/10.1111/j.1540-6261.2006.00890.x

Ritter, J., \& Welch, J. (2002). A review of IPO activity, pricing, and allocations. Journal of Finance, 57(4), 1795-1828. https://doi.org/10.1111/1540-6261.00478

Sun, N., Salama, A., Hussainey, K., \& Habbash, M. (2010). Corporate environmental disclosure, corporate governance and earnings management. Managerial Auditing Journal, 25(7), 679-701. https://doi.org/10.1108/02686901011061351

Tan, H.C., \& Jamal, K. (2006). Effect of accounting discretion on ability of managers to smooth earnings. Journal of Accounting and Public Policy, 25(5), 554-573. https://doi.org/10.1016/j.jaccpubpol.2006.07.007

Teoh, S.H., Welch, I., \& Wong, T.J. (1998). Earnings management and the underperformance of seasoned equity offerings. Journal of Financial Economics, 50(1), 63-99. https://doi.org/10.1016/S0304-405X(98)00032-4

Tong, Y.H., \& Miao, B. (2011). Are dividends associated with the quality of earnings? Accounting Horizons, 25(1), 183-205. https://doi.org/10.2308/acch.2011.25.1.183

Venkataraman, R., Weber, J.P., \& Willenborg, M. (2008). Litigation risk, audit quality, and audit fees: Evidence from initial public offerings, The Accounting Review, 83(5), 1315-1345.

https://doi.org/10.2308/accr.2008.83.5.1315

Zalata, A., \& Roberts, C. (2016). Internal corporate governance and classification shifting practices: An analysis of U.K. corporate behavior. Journal of Accounting, Auditing, and Finance, 31(1), 51-78. https://doi.org/10.1177/0148558X15571736

Zheng, S.X., \& Stangeland, D.A. (2007). IPO underpricing, firm quality, and analyst forecasts. Financial Management, 36(2), 45-64. https://doi.org/10.1111/j.1755-053X.2007.tb00086.x 
Appendix A. Variable Definitions

\begin{tabular}{|c|c|c|}
\hline Variables & & Definitions \\
\hline$E Q_{i}$ & $=$ & $\begin{array}{l}\text { The respective earnings quality metric. We measure the IPO prospectus earnings quality } \\
\text { using four proxies: Jones (1991) model, the modified Jones (1991) model (Dechow et al., } \\
\text { 1995), discretionary accruals controlling for ROA (Kothari et al., 2005), and an aggregate } \\
\text { index of the previous three models. All discretionary accrual measures are reverse coded. }\end{array}$ \\
\hline Lnunder & $=$ & $\begin{array}{l}\text { Natural logarithm of IPO underpricing. IPO Underpricing }=\text { (first day closing price }- \text { offer } \\
\text { price)/offer price. }\end{array}$ \\
\hline Ability $_{1}$ & $=$ & Demerjian et al. (2012) manager ability measure. \\
\hline Ability $_{2}$ & $=$ & Natural logarithm of CEO cash compensation, including salary and bonus. \\
\hline Ability $_{3}$ & $=$ & $\begin{array}{l}\text { Natural logarithm of the number of years an executive has been listed as CEO by } \\
\text { Execucomp as of one year prior to the IPO. }\end{array}$ \\
\hline Stdcflow & $=$ & $\begin{array}{l}\text { The standard deviation (over } 5 \text { years) of IPO firm's pre-IPO cash flow from operations } \\
\text { scaled by total assets. The SEC requires companies to disclose selected financial } \\
\text { information for up to five years prior to the IPO. }\end{array}$ \\
\hline Stdsales & $=$ & $\begin{array}{l}\text { The standard deviation (over } 5 \text { years) of IPO firm's pre-IPO sales scaled by total assets. } \\
\text { The SEC requires companies to disclose selected financial information for up to five years } \\
\text { prior to the IPO. }\end{array}$ \\
\hline Opercycle & $=$ & Natural logarithm of IPO firm's operating cycle in the pre-IPO period. \\
\hline NegEarn & $=$ & $\begin{array}{l}\text { An indicator variable equal to one if firm } i \text { reported negative values of net income before } \\
\text { extraordinary items in their prospectus and zero otherwise. }\end{array}$ \\
\hline CapIntensity & $=$ & IPO firm’s average net Property Plant \&Equipment as a percentage of total assets. \\
\hline Intpdummy & $=$ & $\begin{array}{l}\text { An indicator variable equal to one if the IPO initial offer price is an integer, and zero } \\
\text { otherwise. }\end{array}$ \\
\hline NYSEAMEX & $=$ & $\begin{array}{l}\text { An indicator variable equal to one if the IPO firm is listed on the NYSE or AMEX stock } \\
\text { exchange, and zero otherwise. }\end{array}$ \\
\hline Hightech & $=$ & $\begin{array}{l}\text { Following Loughran \& Ritter (2004), an indicator variable equal to one if the firms' } \\
\text { two-digit SIC code is classified as a technological firm, and zero otherwise. }\end{array}$ \\
\hline Topauditor & $=$ & $\begin{array}{l}\text { An indicator variable equal to one if the IPO firm engages a Big four, Big six, or Big eight } \\
\text { auditor, and zero otherwise. }\end{array}$ \\
\hline$V C$ & $=$ & $\begin{array}{l}\text { An indicator variable equal to one if the IPO firm is backed by venture capitalists, and zero } \\
\text { otherwise. }\end{array}$ \\
\hline Priceupdate & $=$ & $\begin{array}{l}\text { IPO initial offer price divided by the mid-point of initial share price range as filed with } \\
\text { SEC. }\end{array}$ \\
\hline Lnprcd & $=$ & Natural logarithm of total proceeds (in millions of dollars). \\
\hline Pureprimary & $=$ & $\begin{array}{l}\text { An indicator variable equal to one if the IPO consists of primary shares only, and zero } \\
\text { otherwise. }\end{array}$ \\
\hline Age & $=$ & The number of years between incorporation and firm $i$ 's IPO date. \\
\hline Topunderwriter & $=$ & $\begin{array}{l}\text { An indicator variable equal to one if IPO the underwriter prestige ranking is greater than or } \\
\text { equal to eight, and zero otherwise. The prestige ranking is based on Carter \& Manaster } \\
\text { (1990) reputation ranking. }\end{array}$ \\
\hline Lnat & $=$ & Natural logarithm of total asset before IPO (in millions of dollars). \\
\hline$B M$ & $=$ & Book value divided by the market value of the IPO. \\
\hline$U M A$ & $=$ & $\begin{array}{l}\text { The unmanaged (expected) portion of total accruals equal to total accruals minus the } \\
\text { managed portion of accruals. }\end{array}$ \\
\hline Sgrowth & $=$ & The growth of sales over the last fiscal year prior to the IPO. \\
\hline Retained & $=$ & The proportion of ownership retained by the original owners \\
\hline Monitor & $=$ & $\begin{array}{l}\text { An indicator variable equal to one if the CEO shareholding percentage is greater than the } \\
\text { median value of CEO shareholding percentage in the sample, and zero otherwise. }\end{array}$ \\
\hline
\end{tabular}


Appendix B. Comparison of pre-IPO COMPUSTAT information with IPO registration statements.

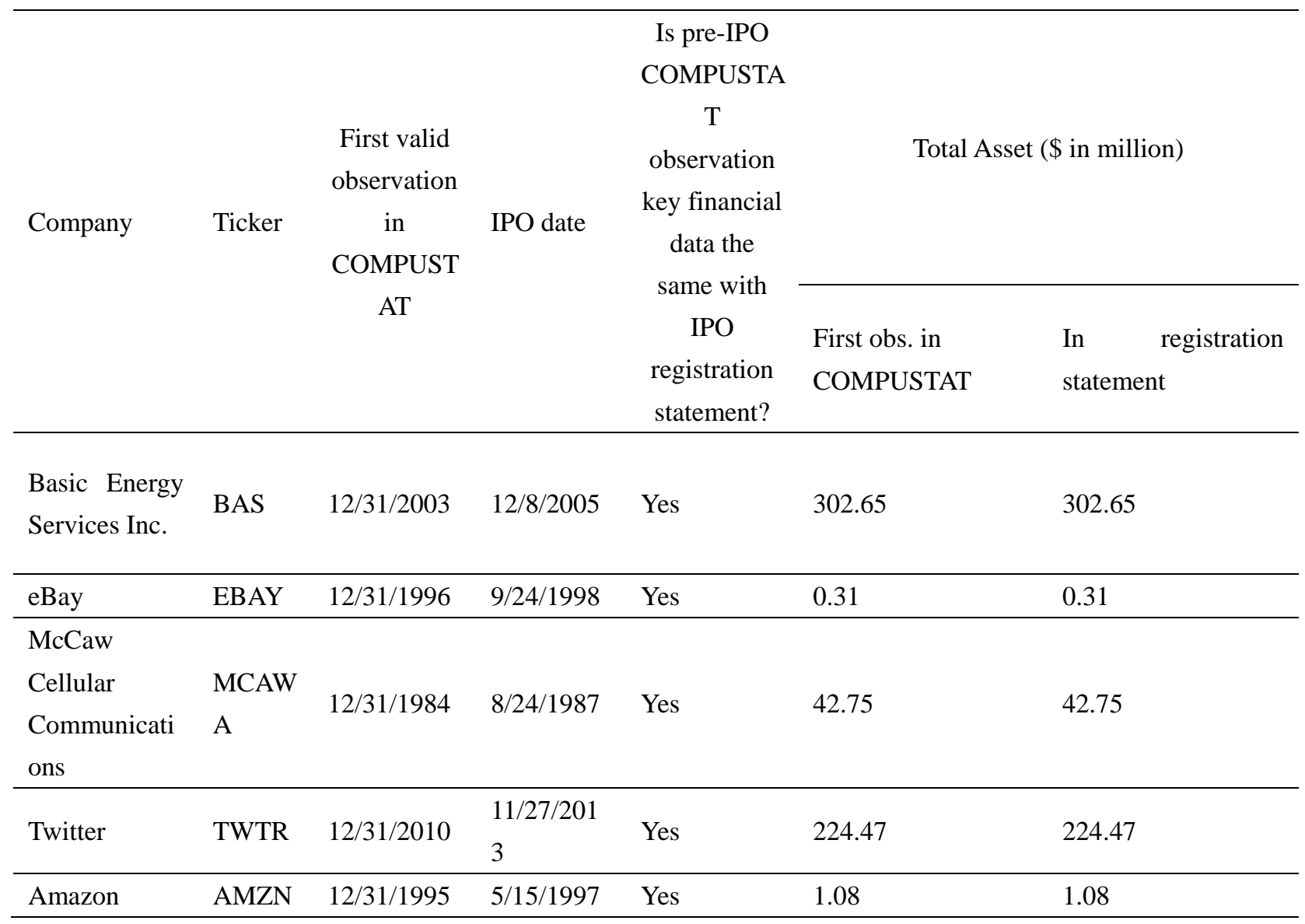

Note: Appendix B reports the results of comparing the total assets reported in COMPUSTAT prior to the IPO date to the financial information reported to the SEC in the IPO Prospectus. To ensure that the values pulled from COMPUSTAT are equal to those in the registration statement, we randomly select five companies from our sample and compared the first available date and financial data in COMPUSTAT to their registration statement. This comparison is aimed to provide some support that the financial information in COMPUSTAT used to calculate MA-Score prior to the IPO date matches the financial information in the IPO prospectus. The SEC generally requires IPO firms to provide five years of selected financial data. However, this varies for emerging growth companies (Revenue $<\$ 1$ billion), that are only required to provide two years of financial data. IPO firms with market values less than $\$ 75$ million dollars are not required to provide any selected financial data. 


\section{Notes}

Note 1. Additionally, prior literature suggests that manager ability influences several factors key to the bargaining power of an issuing firm during their initial public offering (IPO), including financial reporting quality, determination of the percentage of the firm to sell, and the caliber of underwriter and auditor retained for the IPO (Ball \& Shivakumar, 2008; Boulton, Smart, \& Sutter, 2011; Brau \& Johnson, 2009; Butler, Keefe, \& Kieschnick, 2014; Leone, Rock, \& Willenborg, 2007; Ljungqvist, 2007; Teoh, Welch, \& Wong, 1998).

Note 2. Prior literature suggests that institutional investors have strong monitoring incentives given that a lack of due diligence may result in lawsuits, significant losses, and/or reduced investments (O'Brien and Bhushan, 1990; Chung and Zhang, 2011).

Note 3. In order to ensure that the pre-IPO data in COMPUSTAT matches the financial information in the IPO prospectus submitted to the SEC, we compare select financial data reported in the SEC filings to the data pulled from COMPUSTAT for a random sample of firms. We find that the information obtained from COMPUSTAT matches that reported in SEC filings. See Appendix B for details and results of our comparison.

Note 4. We note that the Jumpstart Our Business Startups Act (JOBS Act) was passed in 2012. The 2012 JOBS Act eased the disclosure requirements and regulation for firms going public, which enabled many small firms to go public after the passage of the Act. During the first year after the passage of this Act, IPOs increased 75 percent, and 85 percent in the second year after the Act was passed. As such, we restrict our sample to the period from 1980-2011 to avoid the potential bias on our results caused by the JOBS Act.

Note 5. Our sample size is comparable to Zheng \& Stangeland (2007) and Green \& Hwang (2011). Following Zheng \& Stangeland (2007) sample selection criteria, our sample includes 3,997 IPOs from 1982 to 1998 while their sample includes 3,897 IPOs. Following Green \& Hwang (2011) sample selection criteria, our sample includes 8,098 observations from 1976 to 2011 while Green \& Hwang (2011) has 7,975 observations from 1975 to 2008. Our results remain qualitatively the same if we use alternative sample selection criteria. In addition, we noted that our final sample is not employed in all of our analysis; however, we find that our sample size for our earnings quality and alternative manager ability measures are commensurate with prior research sample sizes (DuCharme et al., 2001; Francis et al., 2008). We use Demerjian et al.'s (2012) MA-Score as our main proxy for manager ability and note that this measure is available beginning in 1980; as such we restrict our sample to observations from 1980-2011.

Note 6. Signed discretionary accruals are a widely accepted method of measuring earnings quality (Teoh et al., 1998; Ducharme et al., 2001). However, we also note that other studies have used unsigned discretionary accruals to measure earnings quality (Hribar \& Nichols, 2007). Hribar \& Nichols (2007) show that tests using the absolute discretionary accruals may be subject to correlated omitted variables, which is a less prevalent issue in research using signed discretionary accruals. As a result, the use of unsigned accrual quality measurements requires additional control variables to reduce the omitted variables problem. In our IPO setting, there is limited financial information available in the IPO prospectus documents; as such, the use of unsigned accruals in our models would result in a significant reduction in sample size.

Note 7. The variables used in this model are defined as follows: Acc is total accrual scaled by lagged total assets, $\Delta R e v$ is equal to revenue in year $t$ less revenues in year $t-1$ scaled by lagged total assets, and PPE is equal to gross property, plant and equipment scaled by lagged total assets.

Note 8 . The additional variable, $\Delta \mathrm{Rec}$ is measured as net accounts receivable in year $\mathrm{t}$ less net receivables in year $\mathrm{t}-1$ scaled by lagged total assets. All other variables are measured as defined in the Jones (1991) model.

Note 9. Kothari et al. (2005) specify that performance matched discretionary accrual can identify earnings management better than controlling for ROA in a linear regression model (used in our main analysis). Sletten, Ertimur, Sunder, and Weber (2018) indicates that using the performance matched accrual method will decrease the IPO sample significantly because of additional requirement for the control firm's ROA. We adopt Kothari et al.'s (2005) linear discretionary regression method because of data limitations for our IPO sample. As a robustness test, we use the performance matching method and our sample decreases significantly. We exclude observations where the difference in ROA between the IPO firm and its matched control is more than 0.1. In untabulated results, our sample decreases more than 30 percent using the performance matched method, but our results remain consistent.

Note 10. The variables used in this model are defined as follows: TAcc is equal to the change in non-cash current assets minus the change in current liabilities excluding the current portion of long-term debt, minus depreciation and amortization, scaled by lagged total assets; $\Delta$ Sales is equal to the change in sales scaled by lagged total assets; PPE is defined as net property, plant and equipment scaled by lagged total assets; ROA is defined as net income scaled by 
average total assets.

Note 11. "DEA is a statistical procedure used to evaluate the relative efficiency of separable entities, called decision-making units (DMUs), where each DMU converts certain inputs into outputs (Demerjian et al. 2012, p. 1232)." In their study, firms are used as the DMUs, and one output is considered based on seven inputs.

Note 12. The output variable used in the model is sales, which is defined as total revenue in year t. Five inputs used in the model are assets the company invests in that are expected to aid in revenue generation. Demerjian et al. (2012) consider the beginning of period balance for each asset and their measures are defined as follows: PPE is defined as net property, plant, and equipment; OpsLease is defined as the discounted present value of the next five years of required operating lease payments; R\&D is calculated following Sougiannis' (1996) net research and development measure; Goodwill is defined as purchased good will reported on the balance sheet; OtherIntan is defined as other acquired and capitalized intangibles also reported on the balance sheet. The remaining two inputs are year t expenses, COGS and SG\&A.

Note 13. The variables in the Tobit regression model are defined as follows: firm efficiency is a value between zero and one estimated using optimization vectors following Demerjian et al. (2012). Total Assets is defined as COMPUSTAT (AT) at the end of year t. Market Share is defined as the percentage of revenues within the firm's Fama and French (1997) industry in year t. Free Cash Flow is a dummy variable that equals one when a firm has non-negative free cash flow (defined as earnings before depreciation and amortization less the change in working capital less capital expenditures) in year t. Firm Age is the number of years that the firm has been recorded in COMPUSTAT. Business Segment Concentration is defined as the ratio of individual business segment sales to total sales, summed across all business segments for year t. Foreign Currency Indicator is a dummy that equals one when a firm reports a nonzero value for foreign currency adjustment in year t. In addition, Demerjian et al. (2012) include year fixed effects, and cluster standard errors by firm and year to control for cross sectional and intertemporal correlation.

Note 14. See Demerjian's website at http://community. Bus.emory.edu/personal/PDEMERJ/Pages/Home.aspx. According to Demerjian et al. (2012), each of the inputs used in the optimization program (model 5) are measured in year $\mathrm{t}-1$, and each variable used in the Tobit regression model (model 6) are estimated in year t. Additionally, for a small group of randomly selected firms we independently verified that the financial information in COMPUSTAT prior to the IPO date matches the financial information in the IPO prospectus submitted to the SEC. See Appendix B. As such, this data is conducive to our purposes of measuring manager ability in an IPO setting.

Note 15. Demerjian et al. (2012) perform the following validity tests to determine the validity of their measure: (1) they find that MA-Score is strongly associated with manager fixed effects, (2) there is a negative (positive) stock price reaction to high ability (low ability) managers leaving the firm, and (3) replacing CEOs with new CEOs of higher ability (lower ability) improves (reduces) subsequent firm performance.

Note 16. IPOs are required by the SEC to disclose five years of selected financial information in their IPO filings. The SDC database contains the pre-IPO data required by the SEC. We use the pre-IPO year as the joint time variable to merge our IPO dataset with COMPUSTAT. This step assures that all the IPO data and control variables from COMPUSTAT are from the pre-IPO period. Due to the fact that only a certain number of IPOs disclose enough pre-IPO information, using Demerjian et al. (2012) regression method of MA-score allows us to calculate the MA-score in the pre-IPO period for a portion of the IPOs. For example, MA-score data is available for Google in December 31th, 2003, although the company's IPO occurred in August 18th, 2004.

Note 17. Compared with Francis et al. (2008), we do not include research and development expense (R\&D expense) in our model. In our IPO sample, 74 percent of the IPOs do not disclose R\&D expense. Inclusion of R\&D expense reduces our sample size by 74 percent, but in untabulated results we find that the results are quantitatively the same when we include R\&D expense.

Note 18. IPO proceeds are adjusted by the Consumer Price Index (CPI).

Note 19. Butler et al. (2014) test the robustness of several different factors used in prior research to explain IPO returns, and their analysis includes 5,573 observations from 1981-2007. The total number of observations used in this study is commensurate to the number of observations that would have been available in our study without inclusion of the financial data sample selection criteria which eliminated 2,877 observations. Bajo \& Raimondo (2017) examine the influence of media sentiment on IPO underpricing and have a comparable sample of 2,814 observations from 1995-2013. We also benchmark our manager ability measures and earnings quality controls against similar studies (Francis et al., 2008; Demerjian et al., 2013), and find that the distribution of our sample is similar. 
Note 20. Our sample's average underpricing is also comparable to a New York Times report that indicates the average underpricing in the past 50 years within U.S. is 16.8 percent. See https://dealbook.nytimes.com/2011/05/27/why-i-p-o-s-get-underpriced/.

Note 21. Our sample covers both a boom and recession period in terms of IPO activity. We use a dummy variable Crisis_Big to control for both the recession and "hot market" effect. In untabulated results, which are available upon request, we also used the percentage of IPO volume over the total number of listed stocks to control for the "hot market" effect. Our results were qualitatively the same when using the alternative measurement. We also added share overhang (measured as the ratio of retained shares to shares offered) to the model as a robustness test. We again find that our results are qualitatively the same.

Note 22. In untabulated results (available upon request), we also perform our analysis of the relationship between earnings quality and manager ability using our other two measures of manager ability, CEO compensation (Ability2) and CEO tenure (Ability3) and find that our results are consistent using each measure. We choose to include our MA-Score (Ability1) results as our main analysis for two reasons, (1) MA-Score is our primary measure of manager ability because of its relevance to the IPO setting, and (2) using our other two manager ability measures results in a significant reduction in sample size and thus may further limit the generalizability of our findings.

Note 23. In untabulated results, we use performance matched discretionary accruals as our measure of earnings quality and note that our results remain consistent with those reported in our main analysis.

Note 24. We note that our sample size fluctuates between our earnings quality and IPO underpricing models. This fluctuation occurs because we use different dependent variables and controls in our regression models. Observations are excluded if they are missing data necessary to calculate our dependent and/or control variables, which results in fluctuations in sample size in our testing. Additionally, we note that IPO firms also disclose limited financial information in their prospectus.

Note 25. Dechow et al. (1995) indicate that the Jones (1991) model has a downward bias of the estimates of discretionary accruals and generates more type II error in detecting discretionary accruals. One quarter of the discretionary accruals estimated using the Jones (1991) model are biased and not detected. As a result, the inconsistent results between the Jones (1991) model (model 1) and modified Jones (1991) model (model 2) may be the result of type II error that has been documented for the Jones (1991) model.

Note 26. CEO ownership is measured as the percentage of shares held by the CEO prior to the IPO.

Note 27. We use an indicator variable for CEO ownership in this analysis for ease of interpretability due to its interaction with manager ability, which is a continuous measure. In untabulated results we perform this analysis using the continuous measure of CEO ownership and we continue to find a significant negative relationship between the interaction term for manager ability and CEO ownership. 